\title{
Lipid biomarkers in Holocene and glacial sediments from ancient Lake Ohrid (Macedonia, Albania)
}

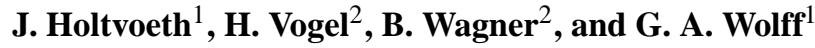 \\ ${ }^{1}$ School of Environmental Sciences, University of Liverpool, 4 Brownlow St, Liverpool, L69 3GP, UK \\ ${ }^{2}$ Institute for Geology and Mineralogy, University of Cologne, Zülpicher Str. 49A, 50674, Köln, Germany
}

Received: 21 May 2010 - Published in Biogeosciences Discuss.: 16 June 2010

Revised: 7 October 2010 - Accepted: 12 October 2010 - Published: 8 November 2010

\begin{abstract}
Organic matter preserved in Lake Ohrid sediments originates from aquatic and terrestrial sources. Its variable composition reflects climate-controlled changes in the lake basin's hydrology and related organic matter export, i.e. changes in primary productivity, terrestrial plant matter input and soil erosion. Here, we present first results from lipid biomarker investigations of Lake Ohrid sediments from two near-shore settings: site Lz1120 near the southern shore, with low-lying lands nearby and probably influenced by river discharge, and site Co1202 which is close to the steep eastern slopes. Variable proportions of terrestrial $n$-alkanoic acids and $n$-alkanols as well as compositional changes of $\omega$ hydroxy acids document differences in soil organic matter supply between the sites and during different climate stages (glacial, Holocene, $8.2 \mathrm{ka}$ cooling event). Changes in the vegetation cover are suggested by changes in the dominant chain length of terrestrial $n$-alkanols. Effective microbial degradation of labile organic matter and in situ contribution of organic matter derived from the microbes themselves are both evident in the sediments. We found evidence for anoxic conditions within the photic zone by detecting epicholestanol and tetrahymanol from sulphur-oxidising phototrophic bacteria and bacterivorous ciliates and for the influence of a settled human community from the occurrence of coprostanol, a biomarker for human and animal faeces (pigs, sheep, goats), in an early Holocene sample. This study illustrates the potential of lipid biomarkers for future environmental reconstructions using one of Europe's oldest continental climate archives, Lake Ohrid.
\end{abstract}

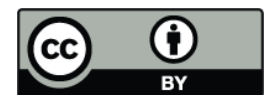

Correspondence to: J. Holtvoeth (j.holtvoeth@liv.ac.uk)

\section{Introduction}

Lake Ohrid is special for a number of reasons. As one of the oldest lakes in the World it potentially preserves the oldest continuous archive of environmental change in Europe, dating back 3-5 million years (Wagner et al., 2008, 2009). It hosts more than 200 endemic species which makes it a unique ecosystem in Europe and, taking its size into account, is the most diverse lake in the world (Albrecht and Wilke, 2008). Finally, it is situated in an intramontaneous basin that belongs to one of only three Mediterranean refugia that were vital for the survival of important groups of plants such as deciduous trees through the hostile climate conditions of the Pleistocene glaciations; the other two were on the southern Iberian Peninsula and in southern Italy (Brewer et al., 2002). It is, therefore, of value for the understanding of the variability of the dominant continental and Mediterranean climate regimes in the southern Balkans over time and the hydrological conditions required for a refuge as well as the evolution of endemic species. The sediments of Lake Ohrid provide a unique archive for the reconstruction of environmental change in high-resolution.

Organic geochemistry provides powerful tools to reconstruct environmental change based on the variable supply of organic matter $(\mathrm{OM})$ from aquatic and terrestrial sources such as phytoplankton, bacteria, macrophytes, land plants and soils as well as anthropogenic sources. This is particularly helpful in settings where the preservation of microfossils is poor. For example, in Lake Ohrid, calcifying ostracods were rarely preserved, or not at all, during the last glacial period (Wagner et al., 2009; Belmecheri et al., 2009). Changing proportions of $\mathrm{OM}$ from the various autochthonous (aquatic) and allochthonous (terrestrial) sources in Lake Ohrid sediments are driven by the hydrological dynamics of the Ohrid

Published by Copernicus Publications on behalf of the European Geosciences Union. 


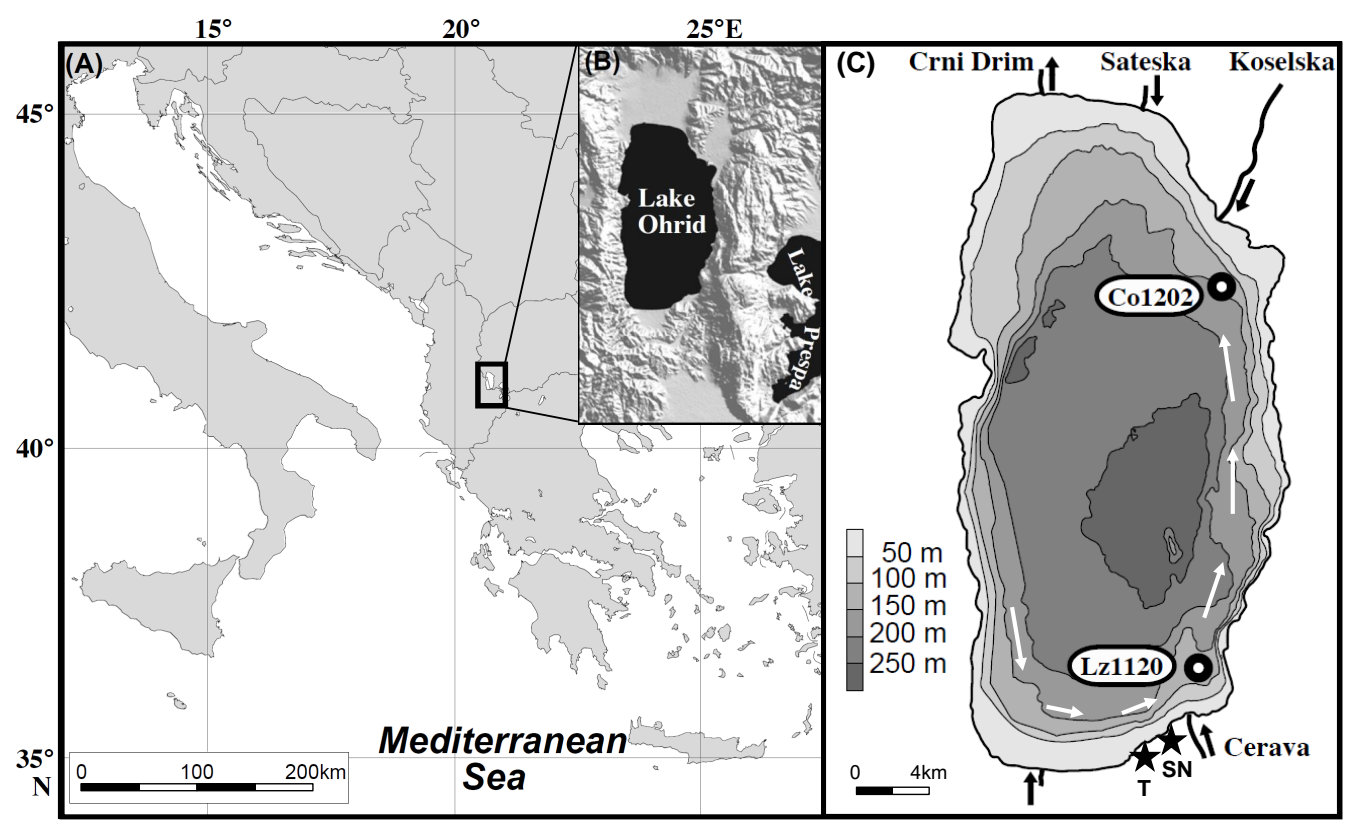

Fig. 1. Maps of SE' Europe (A) and the Lake Ohrid Basin showing the topography and neighbouring Lake Prespa (B), the bathymetry of Lake Ohrid and the positions of sites Lz1120 and Co1202 (C). White arrows indicate the wind-induced surface currents in the catchments of the sites (according to Vogel et al., 2010c). Asterisks mark the karst springs at Tushemisht (T) and Sveti Naum (SN). Note that Lz1120 is influenced by run-off from the low lands at the southern shores, the karst springs and the Cerava River while the catchment of Co1202 includes surface run-off from the steep eastern slopes, only.

Basin. Production of aquatic biomass, for instance, depends on the availability of nutrients that are introduced to the lake mainly through terrestrial run-off. Inputs from the adjacent Lake Prespa, to which Lake Ohrid is connected via karst systems, are negligible since karstic and groundwater sources are depleted in nutrients (Matzinger et al., 2006). With no major river entering the basin, the supply of allochthonous OM depends entirely on the hydrology of the Ohrid Basin itself. Export of plant litter, humus and soil OM from the terrestrial biosphere is controlled by surface drainage and thus depends on local precipitation patterns, vegetation cover, evaporation, moisture storage capacities and soil stability. Here, we provide evidence for changing contributions from the various $\mathrm{OM}$ pools to the sediments under contrasting climatic stages using source-specific lipids.

\section{Material and methods}

Two sediment cores, Lz1120 and Co1202, were taken in 2005 and 2007 from a floating platform using a gravity corer for undisturbed surface sediments and a piston corer for deeper sediments (see Fig. 1 for core positions). Site Lz1120 is situated in the south-eastern area of the lake at $105 \mathrm{~m}$ water depth. The southern shores are less steep than the mountain ranges to the east and include flat areas that once presumably have been flooded. Also nearby are the karst springs of Tushemisht and Sveti Naum (Fig. 1). These and further subaquatic karst springs in the area are fed by overflow from neighbouring Lake Prespa and account for about $50 \%$ of the hydrological inflow of the lake. The Cerava River entering the lake to the south of the site contributes less than $1 \%$ to the total inflow at present (Matzinger et al., 2007). Site Co1202 is located in the northeast in $145 \mathrm{~m}$ water depth. Sedimentation rates at site Lz1120 $(39 \mathrm{~cm} / 1000 \mathrm{a})$ are generally higher than at site Co1202 $(22 \mathrm{~cm} / 1000 \mathrm{a})$ due to the fact that windinduced surface currents rotating counter-clockwise (cf. Vogel et al., 2010c) increase the supply of terrestrial material from the southern shores towards Lz1120 but prevent terrestrial material entering the lake in the Northeast, e.g. by the Koselska River, from reaching site Co1202 (Fig. 1). Composite sediment successions have been obtained by overlapping $3 \mathrm{~m}$ core sections, resulting in contiguous sediment sequences of $11.51 \mathrm{~m}$ and $14.94 \mathrm{~m}$ at Lz1120 and Co1202, respectively. Stratigraphy based on tephrochronology and radiocarbon dates $\left({ }^{14} \mathrm{C}\right)$ has been established for core Lz1120 (Wagner et al., 2009) as well as for core Co1202 (Vogel et al., 2010b). Accordingly, core Lz1120 dates back to $\sim 40 \mathrm{ka}$ with a hiatus between 14.6 and $9.4 \mathrm{ka}$. Core Co1202 dates back to $135 \mathrm{ka}$, with a hiatus between 82 and $97 \mathrm{ka}$.

We have chosen a limited sample set for this study in order to understand how natural variability affects biomarker composition in Lake Ohrid. The criteria of sample selection were based on the existing data of carbonate and OM sedimentation (Fig. 2, data from Wagner et al., 2009). The records of carbonate $\left(\mathrm{CaCO}_{3}\right)$ and total organic carbon (TOC) of 
Lz1120 and Co1202 show climatically controlled environmental changes: almost carbonate-free sediments during the glacial and generally carbonate-rich sediments during the Holocene (Fig. 2). Climate changes of shorter duration and moderate intensity such as the prominent 8.2 ka cooling event also appear in the carbonate and TOC records of both cores. Even though the $\mathrm{CaCO}_{3}$ and TOC minimum around $8 \mathrm{ka}$ occurs somewhat later under the present stratigraphic model at Co1202 than at Lz1120, the almost identical patterns, with a small $\mathrm{CaCO}_{3}$ peak just before the minimum and a strong subsequent increase, suggest that they derive essentially from the same event. Accordingly, we have chosen six samples from site Lz1120: one surface sample, four samples from the Holocene core sections, including one corresponding to the $8.2 \mathrm{ka}$ event, and one glacial sample. Three samples were investigated from core Co1202: one that presumably represents the $8.2 \mathrm{ka}$ event and two from the immediately predating and following Holocene sediment sections. The sediment samples were freeze-dried and homogenised. Total carbon (TC), total nitrogen (TN) and total sulphur (TS) contents were measured using a Vario Micro Cube. TOC was determined after acid digestion of the carbonate fraction (with hydrochloric acid, 16\% v/v). Weight percentages of $\mathrm{CaCO}_{3}$ were then calculated from the difference between TC and TOC measurements using the equation $\mathrm{CaCO}_{3}=(\mathrm{TC}-$ TOC) $\cdot M_{\mathrm{CaCO}_{3}} / M_{\mathrm{C}} ; M_{\mathrm{CaCO}_{3}} / M_{\mathrm{C}} \approx 8.33, M=$ molar mass.

Lipids were extracted from an aliquot of sediment (1-2 g) which was sonicated in a solvent mix of dichloromethane and methanol $(9: 1 ; 45 \mathrm{~min})$. The total lipid extract (TLE) was concentrated and passed through sodium sulphate (anhydrous) to remove any remaining water. Free and bound acids were then trans-methylated by adding a solution of acetyl chloride in methanol (1:30) and leaving the samples at $45^{\circ} \mathrm{C}(12 \mathrm{~h})$. The extracts were then passed through potassium carbonate which removes excess acids (acetic acid, hydrochloric acid). Finally, compounds containing hydroxy groups were derivatised using N,O-bis-(trimethyl-silyl)trifluoroacetamide (with $1 \%$ trimethylchlorosilane; $65^{\circ} \mathrm{C}$, $30 \mathrm{~min})$.

GC-MS analyses of the derivatised TLE were carried out using a Trace 2000 Series gas chromatograph (GC) fitted with a J\&W Scientific DB-5MS capillary column $(60 \mathrm{~m}$, $0.25 \mathrm{~mm}$ i.d.; $5 \%$ phenyl $/ 95 \%$ methylpolysiloxane equivalent phase, $0.1 \mu \mathrm{m}$ film thickness; carrier gas: helium at $1.6 \mathrm{~mL} \mathrm{~min}^{-1}$; on-column injector). The oven temperature was programmed from $60^{\circ} \mathrm{C}$ to $170^{\circ} \mathrm{C}$ at $6^{\circ} \mathrm{C} \mathrm{min}^{-1}$ after $1 \mathrm{~min}$, then to $315^{\circ} \mathrm{C}$ at $2.5^{\circ} \mathrm{C} \mathrm{min}^{-1}$ and held for $10 \mathrm{~min}$. The column was fed directly into a Thermoquest Finnigan TSQ 7000 mass spectrometer (MS). Typical operating conditions were: ionisation potential $70 \mathrm{eV}$; source temperature $215^{\circ} \mathrm{C}$; trap current $300 \mu \mathrm{A}$. Mass data were collected at a resolution of 600, cycling every second from 50-600 Thompsons. Organic compounds were identified from their mass spectra and their relative retention times and in some cases by comparison with authentic standards. They were then quan-

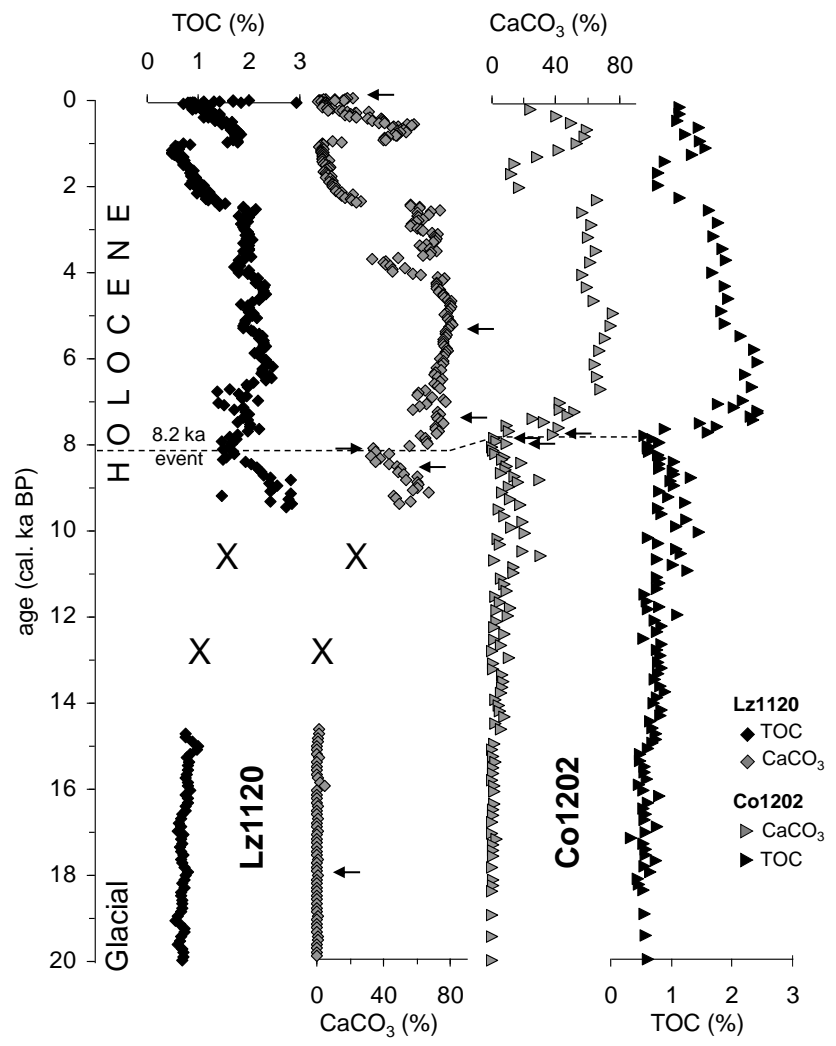

Fig. 2. Weight percentages of carbonate $\left(\mathrm{CaCO}_{3}\right)$ and total organic carbon (TOC) of Lz1120 and Co1202 (X = hiatus in sediments from site Lz1120; data from Wagner et al., 2009). Black arrows mark the samples selected for this study. Although the current stratigraphic model of site Co1202 suggests a lag of the early Holocene minima occurring in both proxies around 7.8 ka relative to similar minima observed around $8.2 \mathrm{ka}$ at site Lz1120 we are confident that these are corresponding features and represent the prominent $8.2 \mathrm{ka}$ cooling event.

tified by relating their peak area to the peak area of the internal standard, $5 \alpha(\mathrm{H})$-cholestane, of which a known amount was added to the samples prior to extraction. The relative response factors of the analytes were determined individually using authentic standards for 35 representative alkanoic acids, $n$-alkanols and sterols. Response factors for analytes where standards were unavailable were assumed to be identical to those of available compounds of the same class.

\section{Results}

\subsection{Elemental analysis}

TOC contents at site Lz1120 range from 0.5 to $2.9 \%$ over the past $20 \mathrm{ka}$ (Fig. 2, data according to Wagner et al., 2009). Sediment samples from the cold climate stage prior to the hiatus $(20-17.4 \mathrm{ka})$ generally contain $<1 \%$ TOC. Highest TOC contents of $\sim 3 \%$ are observed in early Holocene 
Table 1. Elemental data and concentrations of total lipids per gram sample and as percentage of the total organic carbon content (\% $\%$ C); ages according to Wagner et al. (2008) and Vogel et al. (2010b). Based on the correlation of the carbonate and TOC records we assign sample 248 at Co1202 to the 8.2 ka event.

\begin{tabular}{|c|c|c|c|c|c|c|c|c|c|}
\hline & $\begin{array}{r}\text { ID/depth } \\
(\mathrm{cm})\end{array}$ & $\begin{array}{r}\text { age } \\
\text { (cal. ka BP) }\end{array}$ & stage/event & $\begin{array}{r}\text { TOC } \\
(\%)\end{array}$ & $\begin{array}{r}\mathrm{CaCO}_{3} \\
(\%)\end{array}$ & $\begin{array}{r}\mathrm{TOC} / \\
\mathrm{TN}\end{array}$ & $\begin{array}{r}\mathrm{TOC} / \\
\mathrm{TS}\end{array}$ & $\begin{array}{r}\text { lipids } \\
\left(\mu \mathrm{g} / \mathrm{g}_{\mathrm{Sed}}\right)\end{array}$ & $\begin{array}{r}\text { lipids } \\
(\% \text { TOC })\end{array}$ \\
\hline \multirow[t]{6}{*}{ Lz1120 } & 1 & -0.050 & surface & 2.0 & 4.9 & 9 & 59 & 6.6 & 3.3 \\
\hline & 399 & 5.330 & Holocene & 2.1 & 61 & 12 & 62 & 6.4 & 3.1 \\
\hline & 483 & 7.530 & " & 2.0 & 59 & 10 & 77 & 4.0 & 2.0 \\
\hline & 505 & 8.167 & 8.2 event & 1.7 & 35 & 8 & 24 & 2.1 & 1.2 \\
\hline & 517 & 8.526 & Holocene & 2.2 & 48 & 10 & 83 & 4.6 & 2.1 \\
\hline & 643 & 18.900 & Glacial & 0.6 & 0 & 6 & 33 & 0.3 & 0.4 \\
\hline \multirow[t]{3}{*}{ Co1202 } & 246 & 7.723 & Holocene & 1.6 & 39 & 9 & 28 & 1.4 & 0.8 \\
\hline & 248 & 7.797 & 8.2 event & 0.6 & 1 & 6 & 11 & 0.6 & 1.1 \\
\hline & 252 & 7.945 & Holocene & 0.8 & 9 & 7 & 17 & 1.0 & 1.3 \\
\hline
\end{tabular}

samples $(9.4-8.8 \mathrm{ka})$. Carbonate contents range from 0 to $81 \%$ with values close to zero prior to the hiatus (Fig. 2). The Holocene section shows generally high values, with two remarkable drops, one around $8.2 \mathrm{ka}$ and another around $4 \mathrm{ka}$ (Fig. 2). At site Co1202, both TOC and carbonate contents are in a very similar range and show a similar pattern compared to Lz1120. Even though there are some leads and lags between the two records, which most likely result from uncertainties of the age models of both cores, changes in carbonate sedimentation can clearly be correlated. In contrast to Lz1120, however, there is no early Holocene maximum in TOC contents at site Co1202 (Fig. 2; Vogel et al., 2010a).

The elemental data of the investigated samples are summarised in Table 1 . The TOC/TN ratios are generally higher at Lz1120 (average: 9) compared to Co1202 (average: 7) suggesting that terrestrial input is higher at the southern position. The lowest values at both sites are observed in the samples representing the $8.2 \mathrm{ka}$ event and the glacial, presumably due to the fact that these climate stages were drier and terrestrial run-off reduced. The TOC/TS ratio reveals a very similar pattern, with generally lower values at site Co1202 and minimum values during the drier climate stages, which may result from both changing OM quantities supplied to the sediments and different proportions of terrestrial and aquatic $\mathrm{OM}$ as well as different levels of OM degradation.

\subsection{Lipid biomarkers}

We quantified normal, branched, mono-unsaturated and hydroxy alkanoic acids (as methyl esters), $n$-alkanols, $n$-alkanes, sterols and some miscellaneous compounds including a $\mathrm{C}_{15}$ branched alkanol, $\beta$-amyrin, $17 \beta(\mathrm{H})$, $21 \beta(\mathrm{H})$-bishomohopanoic acid and $17 \beta(\mathrm{H}), 21 \beta(\mathrm{H})$ bishomohopanol. The amounts of compounds and groups of compounds relevant for detailed discussion as well as their sources are listed in Table 2. A detailed list of all individ- ually quantified compounds is available as supplementary data. In the following, amounts of lipid compounds will be given as percentages either of the TOC content (\% $\%$ TOC) or of the TLE (\% $\left.\%_{\text {lipids }}\right)$.

The amounts of extracted lipids from the Holocene samples of Co1202 are lower $\left(0.6-1.4 \mu \mathrm{g}_{\text {lipids }} / \mathrm{g}_{\text {Sed }}\right)$ than those from Lz1120 $\left(2.1-6.6 \mu \mathrm{g}_{\text {lipids }} / \mathrm{g}_{\mathrm{Sed}}\right)$ mirroring the differences in TOC contents (Table 1). This observed offset between the sites, however, may not be extrapolated to the entire sedimentary record, in particular when it comes to phases of anthropogenic modification of the environment through deforestation of large areas of the Balkans after $\sim 4.5 \mathrm{ka}$ (Willis, 1994). The lowest concentration of lipids $\left(0.3 \mu \mathrm{g}_{\text {lipids }} / \mathrm{g}_{\mathrm{Sed}}\right)$ was detected in the glacial sample from Lz1120). The samples presumed to represent the $8.2 \mathrm{ka}$ event from both cores also reveal lower concentrations of lipids. The overall lower percentages of extractable lipids relative to the TOC content in samples from Co1202 suggest a higher proportion of non-extractable organic carbon in stable biopolymers such as lignin or cellulose in terrestrial plant tissues or black carbon. This may result from a primarily increased supply of these compounds or from their higher preservation potential during early organic matter diagenesis. High amounts of extractable lipids in the surface sample of Lz1120 (3.3\% TOC), on the other hand, result from a high proportion of relatively labile organic compounds such as the mono-unsaturated alkanoic acids $(0.4 \%$ TOC $)$ and branched alkanoic acids $(0.1 \%$ TOC $)$ that are not completely degraded by microbial consumption even though this process is most intense near the sediment-water interface.

The major compound classes of the TLE's from Lz1120 and Co1202 are $n$-alkanoic acids and $n$-alkanols (Fig. 3), together accounting from $48 \%$ lipids (surface sample, Lz1120) to $91 \%$ lipids $(7.9 \mathrm{ka}, \mathrm{Co1202})$. Differences in their proportions are evident between the two sites as well as between the 
Table 2. Compounds quantified in total lipid extracts from sites Lz1120 and Co1202 as percentages of the total of quantified lipids.

\begin{tabular}{|c|c|c|c|c|c|c|c|c|c|c|c|}
\hline $\begin{array}{l}\text { core } \\
\text { sample ID/composite depth (cm) } \\
\text { age (cal. yrs. BP) }\end{array}$ & $\begin{array}{r}\text { Lz1 } 120 \\
1 \\
-50\end{array}$ & $\begin{array}{r}\text { Lz1 } 120 \\
399 \\
5330\end{array}$ & $\begin{array}{r}\text { Lz1 } 120 \\
483 \\
7530\end{array}$ & $\begin{array}{r}\text { Lz1120 } \\
505 \\
8167\end{array}$ & $\begin{array}{r}\text { Lz1120 } \\
517 \\
8526\end{array}$ & $\begin{array}{r}\text { Lz1120 } \\
643 \\
18900\end{array}$ & $\begin{array}{r}\mathrm{Co} 1202 \\
246 \\
7723\end{array}$ & $\begin{array}{r}\text { Co1202 } \\
248 \\
7797\end{array}$ & $\begin{array}{r}\mathrm{Co} 202 \\
252 \\
7945\end{array}$ & sources & references \\
\hline \multicolumn{12}{|l|}{ lipid fractions (\%) } \\
\hline$n$-alkanoic acids (FA) & 30.1 & 39.9 & 32.6 & 22.6 & 41.4 & 24.6 & 63.4 & 26.7 & 62.4 & & \\
\hline hydroxy acids (OH-FA) & 1.0 & 4.7 & 3.7 & 2.7 & 3.7 & 5.9 & 1.3 & 1.1 & 0.2 & & \\
\hline branched fatty acids & 2.8 & 0.6 & 0.4 & 0.9 & 0.9 & - & - & - & - & & \\
\hline unsaturated fatty acids & 12.2 & 0.2 & - & 0.04 & 0.2 & - & - & - & - & & \\
\hline$n$-alkanols & 18.0 & 31.6 & 22.8 & 44.8 & 28.2 & 43.2 & 25.9 & 56.0 & 28.3 & & \\
\hline$n$-alkanes & 2.3 & 1.6 & 2.4 & 2.1 & 1.5 & 9.7 & 2.0 & 3.0 & 2.1 & & \\
\hline sterols & 24.8 & 12.1 & 25.4 & 20.2 & 14.2 & 11.0 & 5.4 & 9.9 & 4.7 & & \\
\hline others & 8.8 & 9.2 & 12.7 & 6.6 & 9.8 & 5.5 & 2.0 & 3.3 & 2.2 & & \\
\hline \multicolumn{12}{|l|}{$n$-alkanoic acids } \\
\hline$\Sigma \mathrm{C}_{14}-\mathrm{C}_{19} \mathrm{FA}$ (short-chain) & 12.0 & 13.9 & 5.2 & 13.8 & 10.6 & 2.9 & 26.6 & 15.7 & 6.7 & phytoplankton, bacteria & Meyers and Ishiwatari (1993), \\
\hline$\Sigma \mathrm{C}_{20}-\mathrm{C}_{23} \mathrm{FA}$ (mid-chain) & 5.5 & 3.8 & 5.6 & 4.3 & 7.0 & 3.6 & 9.7 & 4.7 & 8.1 & variable & Meyers (1997) \\
\hline $\begin{array}{l}\Sigma \mathrm{C}_{24}-\mathrm{C}_{33} \mathrm{FA} \text { (long-chain) } \\
\text { hdrox acids }\end{array}$ & 12.6 & 22.2 & 21.7 & 4.5 & 23.9 & 18.2 & 27.1 & 6.3 & 47.7 & higher plants & \\
\hline $\begin{array}{l}\text { hydroxy acids } \\
\omega \text { - } \mathrm{C}_{16} \text { OH-FA }\end{array}$ & 0.31 & 0.83 & 0.82 & 0.40 & 0.97 & 0.49 & 0.21 & 0.30 & 0.10 & cutin, suberin & Kolattukudy (1980), \\
\hline$\omega-\mathrm{C}_{18} \mathrm{OH}-\mathrm{FA}$ & - & 0.05 & 0.05 & - & 0.04 & 0.14 & - & - & - & cutin & Bull et al. (2000) \\
\hline$\omega$-C $\mathrm{C}_{22} \mathrm{OH}-\mathrm{FA}$ & 0.49 & 1.07 & 0.78 & 0.20 & 0.48 & 1.42 & 0.17 & 0.15 & 0.04 & suberin & Bull et al. (2000), \\
\hline$\omega-\mathrm{C}_{24} \mathrm{OH}-\mathrm{FA}$ & - & 1.22 & 0.81 & 0.11 & 0.45 & 1.78 & 0.24 & 0.08 & - & suberin & Nierop et al. (2005) \\
\hline$\Sigma \alpha$-hydroxy acids & - & - & 0.12 & 1.63 & 0.38 & - & 0.13 & 0.44 & - & bacteria & Fukushima et al. (1992) \\
\hline & 0.99 & 4.74 & 3.54 & 1.12 & 3.32 & 5.93 & 1.14 & 0.62 & \multicolumn{3}{|c|}{ branched fatty acids } \\
\hline $\begin{array}{l}\Sigma \mathrm{C}_{15}-\mathrm{C}_{18} \text { branched } \mathrm{FA} \\
\text { (iso- and anteiso-) }\end{array}$ & 2.75 & 0.62 & 0.38 & 0.94 & 0.94 & - & - & - & - & bacteria & $\begin{array}{l}\text { Cranwell (1980), } \\
\text { Goosens et al. (1989), } \\
\text { van Bergen et al. (1998) }\end{array}$ \\
\hline \multicolumn{12}{|l|}{ unsaturated fatty acids } \\
\hline $\mathrm{C}_{16: 1}, \mathrm{C}_{18: 1} \mathrm{FA}$ & 12.23 & 0.23 & - & 0.04 & 0.18 & - & - & - & - & $\begin{array}{l}\text { phytoplankton, bacteria, } \\
\text { microalgae }\end{array}$ & $\begin{array}{l}\text { Bobbie and White (1980), } \\
\text { Kattner et al. (1983), } \\
\text { Ahlgren et al. (1992) }\end{array}$ \\
\hline \multicolumn{12}{|l|}{$n$-alkanols } \\
\hline$\Sigma \mathrm{C}_{12}-\mathrm{C}_{19} \mathrm{OH}$ (short-chain) & 3.9 & 0.3 & 0.5 & 1.4 & 1.1 & 1.2 & 3.7 & 5.7 & 1.2 & phytoplankton, bacteria & Meyers and Ishiwatari (1993), \\
\hline$\Sigma \mathrm{C}_{20}-\mathrm{C}_{23} \mathrm{OH}$ (mid-chain) & 6.1 & 7.1 & 4.2 & 6.2 & 3.6 & 14.0 & 4.6 & 10.2 & 5.2 & microalgae, epiphytes & Jaffé et al. (2001), \\
\hline$\Sigma \mathrm{C}_{24}-\mathrm{C}_{33} \mathrm{OH}$ (long-chain) & 8.0 & 24.2 & 18.0 & 37.2 & 23.6 & 28.1 & 17.6 & 40.1 & 21.8 & higher plants & $\begin{array}{l}\text { Volkman et al. (1999), } \\
\text { Ficken et al. (2002) }\end{array}$ \\
\hline \multicolumn{12}{|l|}{$n$-alkanes } \\
\hline$\Sigma \mathrm{C}_{12}-\mathrm{C}_{19}$ (short-chain) & - & - & - & - & - & - & - & - & - & phytoplankton, bacteria & Meyers and Ishiwatari (1993), \\
\hline$\Sigma \mathrm{C}_{20}-\mathrm{C}_{25}$ (mid-chain) & 0.96 & 0.30 & 0.58 & 0.42 & 0.21 & 2.23 & 0.52 & 0.71 & 0.38 & macrophytes & Ficken et al. (2002) \\
\hline \\
\hline coprostanol & 0.75 & - & - & - & 0.11 & - & - & - & - & human faeces & Sherwin et al. (1993), \\
\hline epicoprostanol & 0.77 & - & - & - & - & - & - & - & - & faeces of higher mammals & Bull et al. (2002) \\
\hline epicholestanol & 0.64 & 0.25 & 0.70 & 0.34 & 0.22 & - & - & 0.12 & - & phototrophic sulphur bacteria & Robinson et al. (1984) \\
\hline cholesterol & 5.93 & 2.10 & 3.00 & 1.80 & 1.63 & 1.08 & 0.60 & 1.85 & 0.58 & non-specific; zooplankton, & Volkman (1986), \\
\hline cholestanol & 3.38 & 1.08 & 2.92 & 1.98 & 0.91 & 2.06 & 0.52 & 0.78 & 0.19 & dinofagellates, diatoms & $\begin{array}{l}\text { Goosens et al. (1989), } \\
\text { Thiel et al. (1997) }\end{array}$ \\
\hline stigmasterol & 2.21 & 0.62 & 0.92 & 0.33 & 0.29 & - & - & - & - & & \\
\hline sitosterol & 4.65 & 2.55 & 5.43 & 2.07 & 2.14 & 4.48 & 0.85 & 1.80 & 1.58 & higher plants, also diatoms & Volkman $(1986,2005)$ \\
\hline stigmastanol & 3.42 & 2.59 & 2.12 & 5.00 & 2.81 & 3.38 & 1.06 & 1.62 & 0.86 & & \\
\hline dinosterol & - & - & 1.98 & 1.01 & 1.39 & - & 0.38 & 0.38 & 0.19 & dinoflagellates & Volkman (1986) \\
\hline $\begin{array}{l}\mathrm{C}_{30} \text { 4-methyl stanols } \\
\text { (incl. dinostanol) }\end{array}$ & 1.18 & - & 3.07 & 1.42 & 1.40 & - & 1.30 & 2.09 & 0.98 & & \\
\hline lanosterol & 1.82 & 2.94 & 5.26 & 5.03 & 3.06 & 0.01 & 0.67 & 1.24 & 0.33 & fungi, animals, dinoflagellates & $\begin{array}{l}\text { Volkman (2005), } \\
\text { Al-Mutlaq et al. (2008) }\end{array}$ \\
\hline \multicolumn{12}{|r|}{ 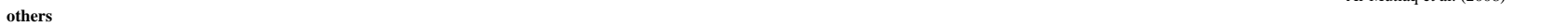 } \\
\hline$\beta$-amyrin & 0.20 & 0.42 & 0.73 & 0.93 & 0.57 & 0.59 & 0.24 & 0.92 & - & higher plants & Volkman (2005) \\
\hline tetrahymanol & 1.87 & 0.64 & 1.17 & 1.26 & 0.69 & 0.18 & 0.08 & 0.13 & 0.04 & ciliates, unaerobic phototrophic bacterium & $\begin{array}{l}\text { Harvey and Mcmanus (1991), } \\
\text { Kleemann et al. (1990) }\end{array}$ \\
\hline $17 \beta(\mathrm{H}), 21 \beta(\mathrm{H})$-bishomohopanol & 0.48 & 1.39 & - & 1.29 & 0.71 & 0.43 & 0.18 & 0.35 & 0.10 & bacteria in soils and sediments & Ries-Kautt and Albrecht (1989), \\
\hline $17 \beta(\mathrm{H}), 21 \beta(\mathrm{H})$-bishomohopanoic acid & 3.14 & 6.02 & 9.17 & 2.43 & 6.38 & 2.76 & 1.49 & 1.92 & 1.78 & & Innes et al. (1997) \\
\hline$\Sigma$ branched $\mathrm{C}_{15}, \mathrm{C}_{16}, \mathrm{C}_{17}, \mathrm{C}_{22}$ alkanols & 1.73 & 0.18 & 0.38 & 0.65 & - & 1.13 & - & - & - & bacteria & $\begin{array}{l}\text { Cranwell (1980), } \\
\text { Thiel et al. (1997) }\end{array}$ \\
\hline
\end{tabular}

Holocene samples and the samples representing the glacial and the $8.2 \mathrm{ka}$ event (Fig. 3). However, there were more subtle differences in the contribution of minor compounds and, more important, in the distribution of single compounds within the various compound classes (e.g., long-chain vs. short-chain alkanoic acids).

\section{$3.3 n$-alkanoic acids}

Highest proportions of saturated $n$-alkanoic acids (also: $n$ fatty acids, short: $n$ - $\mathrm{C}_{x} \mathrm{FA}$ ) occur in the Holocene samples 252 and 246 of core Co1202 accounting for 62 and $63 \%$ of the total lipids, respectively (Fig. 3, Table 2). By far lowest proportions in each core were found in the samples representing the $8.2 \mathrm{ka}$ event at both sites, $23 \%$ lipids (Lz1120, sample
$505)$ and $27 \%$ lipids (Co1202, sample 248), as well as in the glacial sample from Lz1120 (sample 643) with $25 \%$ lipids saturated $n$-alkanoic acids (Fig. 3 ). The observed chain lengths of the $n$-alkanoic acids range from $\mathrm{C}_{14}$ to $\mathrm{C}_{32}$. Most samples show a bimodal distribution maximising at $\mathrm{C}_{16}$ and $\mathrm{C}_{24}$ or $\mathrm{C}_{26}$ (Fig. 4). Short-chain $n$-alkanoic acids, in particular $n-\mathrm{C}_{16}$ and $n-\mathrm{C}_{18} \mathrm{FA}$, derive mainly from phytoplankton whereas long-chain $n$-alkanoic acids $\left(n-\mathrm{C}_{24}\right.$ to $n$ - $\left.\mathrm{C}_{32} \mathrm{FA}\right)$ derive from the leaf waxes of terrestrial plants (e.g., Meyers and Ishiwatari, 1993; Ficken et al., 2002). Highest proportions of phytoplankton-derived $n-\mathrm{C}_{16}$ and $n-\mathrm{C}_{18}$ FA relative to terrestrial $\mathrm{C}_{24}-\mathrm{C}_{28}$ FAs were observed in sample 505 from Lz1120 and sample 248 from Co1202, representing the $8.2 \mathrm{ka}$ event (Fig. 4). Terrestrial FAs appear strongly depleted in these samples. This is illustrated in Table 3 by very low values 

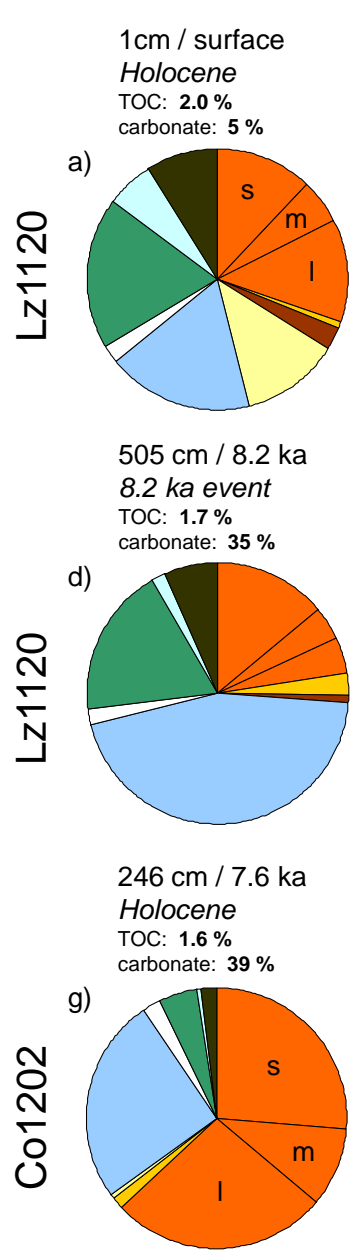
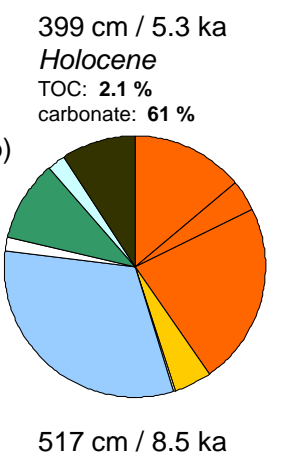

Holocene

TOC: $2.2 \%$

carbonate: $48 \%$

e)

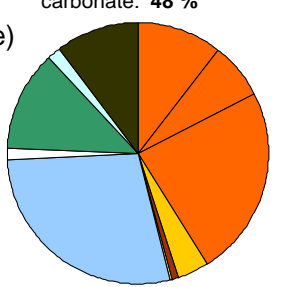

$248 \mathrm{~cm} / 7.8 \mathrm{ka}$ corresp. to 8.2 event TOC: $0.6 \%$

carbonate: $1 \%$

h)

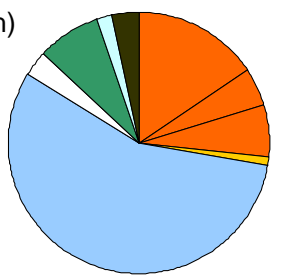

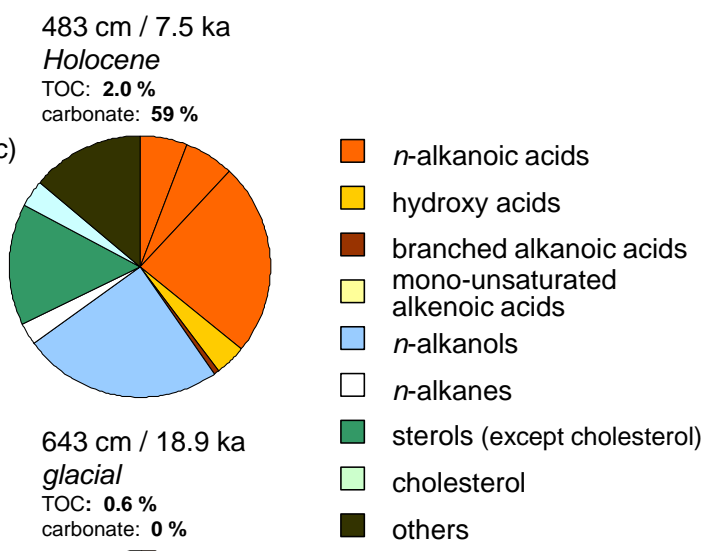

f)

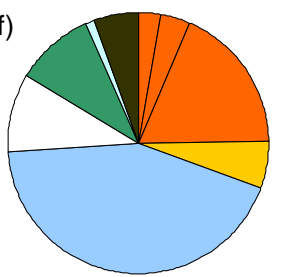

$252 \mathrm{~cm} / 7.9 \mathrm{ka}$

Holocene

TOC: $0.8 \%$

carbonate: $9 \%$

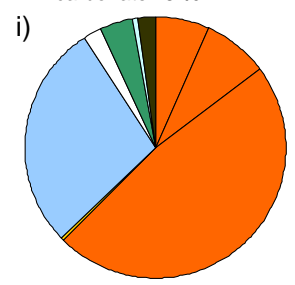

Fig. 3. Composition of total lipid extracts of samples from sites Lz1120 (a-f) and Co1202 (g-i). The segments within the $n$-alkanoic acid signature represent (clockwise) short- (s), mid- (m) and long-chain (l) $n$-alkanoic acids. Note the considerably higher proportions of $n$-alkanoic acids at site Co1202 and the increased amounts of $n$-alkanols in samples from the 8.2 ka event and the glacial. Labile unsaturated $n$-alkanoic acids are present in significant amounts in the surface sample, only.

of the terrestrial/aquatic ratio of the FAs $\left(\mathrm{TAR}_{\mathrm{FA}}\right)$ calculated according to Bourbonniere and Meyers (1996). Among the long-chain terrestrial fraction, where present, the dominating $n$-alkanoic acids are $n-\mathrm{C}_{24}$ and $n$ - $\mathrm{C}_{26}$ FA. While $n$ $\mathrm{C}_{24}$ dominates in the surface sample (Lz1120) and the samples representing the $8.2 \mathrm{ka}$ event, $n-\mathrm{C}_{26}$ FA either dominates or is present in equal concentrations in all other samples. This quasi alternating behaviour suggests that there are two terrestrial OM sources with slightly different maxima in their $n$-alkanoic acid distributions. Further information can be gained from the ratio of even- over odd-numbered carboxylic compounds, the carbon preference index (CPI). This proxy is often used to assess the level of FA degradation based on the fact that unaltered biological material usually shows a strong even-over-odd predominance of its FAs whereas microbially altered material reveals higher amounts of odd-numbered FAs and, accordingly, lower CPI values. Matsudo and Koyama (1977) introduced a modification of the CPI for the application on FAs of high molecular weight $\left(\mathrm{CPI}_{\mathrm{H}}\right.$, range: $\left.\mathrm{C}_{22}-\mathrm{C}_{32}\right)$ using the equation $\mathrm{CPI}_{\mathrm{H}}=\left(\Sigma \mathrm{C}_{22}-\right.$ $\left.\mathrm{C}_{30}+\Sigma \mathrm{C}_{24}-\mathrm{C}_{32}\right) / 2 \times \Sigma \mathrm{C}_{23}-\mathrm{C}_{31}$. Accordingly, the proportion of odd-numbered long-chain $n$-alkanoic acids $\left(n-\mathrm{C}_{23}\right.$ to $n$ - $\mathrm{C}_{31}$ ) is slightly increased only in the glacial sample from Lz1120 (Fig. 4b) resulting in the lowest observed $\mathrm{CPI}_{\mathrm{H}}$ value of 4.0 (Table 3). No odd-numbered FAs with carbon numbers greater than $\mathrm{C}_{27}$ were identified in samples 505 from Lz1120 and 248 from Co1202 representing the $8.2 \mathrm{ka}$ event in both cores which results in $\mathrm{CPI}_{\mathrm{H}}$ values $>20$. The $\mathrm{CPI}_{\mathrm{H}}$ values of all other samples range from 7.8 to 10.5 and thus suggest a low level of FA degradation (Table 3).

\subsection{Branched alkanoic acids}

Branched alkanoic acids (branched $\mathrm{C}_{x}$ FA) were detected in relatively high amounts in the surface sample of Lz1120 and in small amounts in the Holocene samples. They were 

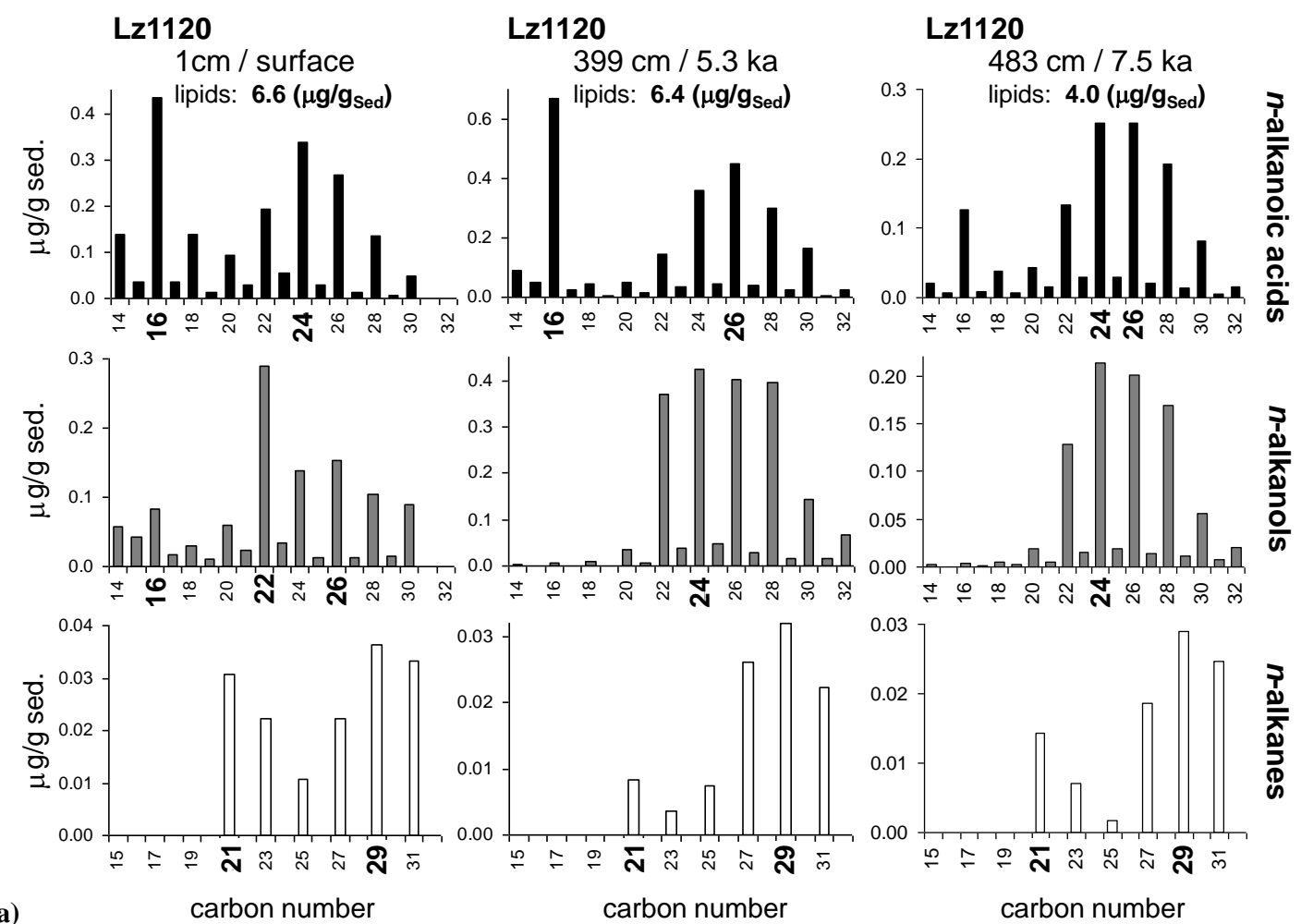

Fig. 4. Distributions of $n$-alkanoic acids (black bars), $n$-alkanols (grey bars) and $n$-alkanes (white bars) in samples from Lz1120 and Co1202. Carbon numbers of some specific compounds (e.g. 16 and 24-28 for aquatic and terrestrial OM, respectively) are highlighted by larger numbers where dominant or indicating bimodal distributions. Samples from the $8.2 \mathrm{ka}$ event are strongly depleted in terrestrial $n$-alkanoic acids relative to terrestrial $n$-alkanols suggesting increased proportions of soil OM enriched in $n$-alkanols. Considerably lower concentrations of lipids (see y-axis values) during the drier climate stages confirm overall lower OM input.

absent, however, in the glacial sample and in the three samples from site Co1202 (Table 2). Iso- and anteiso- $\mathrm{C}_{15}$ FA are the most abundant and the only branched FA found in samples $399(5.3 \mathrm{ka})$ and $483(7.5 \mathrm{ka})$. The surface sample furthermore contains iso- and anteiso- $\mathrm{C}_{17} \mathrm{FA}$, some anteiso$\mathrm{C}_{16}$ FA and a small amount of a $\mathrm{C}_{18}$ branched FA together accounting for $38 \%$ of the total branched FAs. Apart from this, only the early Holocene sample $(517,8.5 \mathrm{ka})$ contains a small amount of iso- $\mathrm{C}_{16}$ FA. Branched FA, in particular branched iso- and anteiso- $\mathrm{C}_{15}$ FA, derive from bacteria living in sediments as well as in soils (Cranwell, 1973; Goosens et al., 1989; Amblès et al., 1994; van Bergen et al., 1998). Accordingly, microbial organic matter of either sediment or soil origin as indicated by iso- and anteiso- $\mathrm{C}_{15}$ FA is abundant in the surface sample of Lz1120, still detectable in most of the Holocene samples but absent at Co1202.

\subsection{Mono-unsaturated alkenoic acids}

Mono-unsaturated alkenoic acids $\left(\mathrm{C}_{n: 1} \mathrm{FA}\right)$ were detected in considerable amounts only in the surface sample of Lz1120, namely various isomers of $\mathrm{C}_{16: 1} \mathrm{FA}(9.4 \%$ lipids $)$ and $\mathrm{C}_{18: 1} \mathrm{FA}$ $(2.8 \%$ lipids $)$. Both compounds are abundant in phytoplank- ton. Small amounts of $\mathrm{C}_{18: 1} \mathrm{FA}$ are also present in samples 399, 505 and 517 from Lz1120. In these cases, $C_{18: 1}$ FA probably does not derive from phytoplankton since the second unsaturated compound from this source dominating in the surface sample, $\mathrm{C}_{16: 1} \mathrm{FA}$ is absent. Instead, $\mathrm{C}_{18: 1}$ FA might have been synthesised by bacteria living in the sediment (Bobbie and White, 1980). No unsaturated lipids have been detected at Co1202. Unsaturated lipid compounds are generally more susceptible to microbial degradation than their saturated counterparts (Haddad et al., 1992; Meyers and Ishiwatari, 1993). The complete absence of unsaturated compounds other than $\mathrm{C}_{18: 1}$ FA presumably produced in situ at Lz1120 illustrates effective microbial consumption of labile organic matter in the near surface sediments.

\subsection{Hydroxy acids}

Hydroxy acids were found in the sediments at both sites. However, their proportion was clearly higher at Lz1120: 1$6 \%$ lipids compared to $0.2-1.3 \%$ lipids at Co1202. Hydroxy acids are major constituents of the biopolyesters cutin and suberin. Cutin makes up the protective layers of the aerial parts of plants (plant waxes) and contains mainly $\mathrm{C}_{16}$ and $\mathrm{C}_{18}$ 

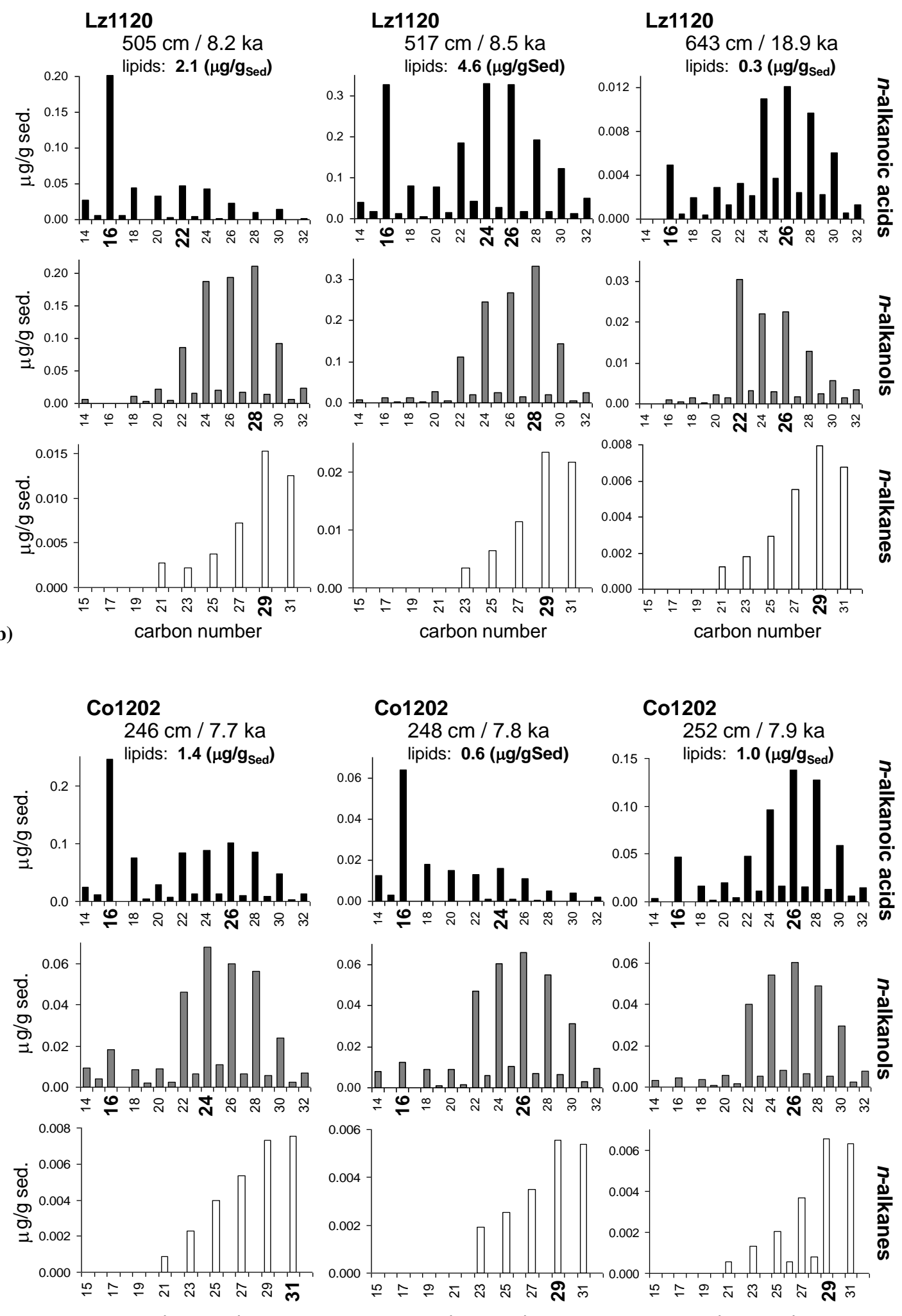

(c)

carbon number

carbon number
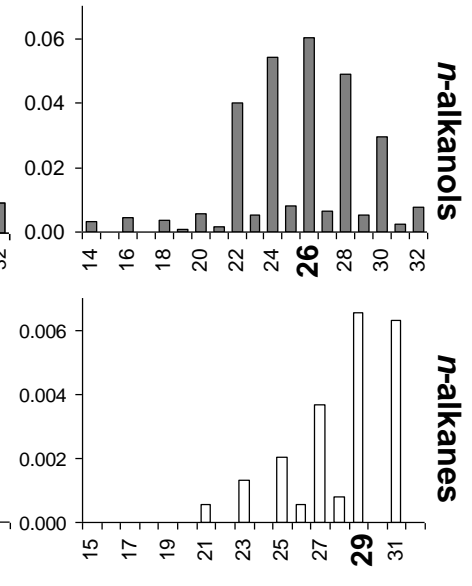

Fig. 4. Continued. 
Table 3. Organic geochemical proxy data based on biomarker distributions and ratios: the terrestrial/aquatic ratio $\left(\mathrm{TAR}_{\mathrm{FA}}=\left(\mathrm{C}_{24}+\mathrm{C}_{26}+\mathrm{C}_{28}\right) /\left(\mathrm{C}_{14}+\mathrm{C}_{16}\right)\right.$; Bourbonniere and Meyers, 1996), the carbon preference index for even- over odd-numbered high-molecular weight $n$-alkanoic acids $\left(\mathrm{CPI}_{\mathrm{H}}=\right.$ $\left(\Sigma \mathrm{C}_{22}-\mathrm{C}_{30}+\Sigma \mathrm{C}_{24}-\mathrm{C}_{32}\right)_{\text {even }} /\left(2 \times \Sigma \mathrm{C}_{23}-\mathrm{C}_{31}\right)_{\text {odd }}$; Matsudo and Koyama, 1977), the proportion of $n$-alkanes derived from aquatic plants $\left(P_{\mathrm{aq}}=\left(\mathrm{C}_{23}+\mathrm{C}_{25}\right) /\left(\mathrm{C}_{23}+\mathrm{C}_{25}+\mathrm{C}_{29}+\mathrm{C}_{31}\right)\right.$; Ficken et al., 2000), the ratio of long-chain $C_{22} \omega$-hydroxy acid over short-chain $\mathrm{C}_{16} \omega$-hydroxy acid $\left(\omega-\mathrm{C}_{22} / \omega-\mathrm{C}_{16}\right.$; Nierop et al., 2009) and the ratio of total $n$-alkanoic acids over $n$-alkanols $\left(\mathrm{FA} / \mathrm{OH}=\Sigma \mathrm{C}_{12}-\right.$ $\mathrm{C}_{32} \mathrm{FA} / \Sigma \mathrm{n}-\mathrm{C}_{12}-\mathrm{C}_{32} \mathrm{OH}$; this study). Minimum concentrations or absence of long-chain terrestrial $n$-alkanoic acids in the samples representing the $8.2 \mathrm{ka}$ event bias the $\mathrm{CPI}_{\mathrm{H}}$ values and result in considerably lower $\mathrm{TAR}_{\mathrm{FA}}$ and $\mathrm{FA} / \mathrm{OH}$ values.

\begin{tabular}{lrrrrrrr}
\hline core & $\begin{array}{r}\text { sample } \\
\text { ID }\end{array}$ & $\begin{array}{r}\text { cal. yrs. } \\
\mathrm{BP}\end{array}$ & TAR $_{\mathrm{FA}}$ & $\mathrm{CPI}_{\mathrm{H}}$ & $\mathrm{P}_{\mathrm{aq}}$ & $\begin{array}{r}\omega-\mathrm{C}_{22} / \\
\omega-\mathrm{C}_{16}\end{array}$ & FA/OH \\
\hline Lz1120 & 1 & -50 & 1.29 & 10.3 & 0.32 & 1.56 & 1.7 \\
& 399 & 5330 & 1.46 & 9.8 & 0.17 & 1.29 & 1.3 \\
& 483 & 7530 & 4.70 & 9.6 & 0.14 & 0.95 & 1.4 \\
& 505 & 8167 & 0.33 & 25.0 & 0.18 & 0.50 & 0.5 \\
& 517 & 8526 & 2.31 & 10.5 & 0.18 & 0.50 & 1.5 \\
& 643 & 18900 & 6.62 & 4.0 & 0.24 & 2.92 & 0.6 \\
Co1202 & & & & & & & \\
& 246 & 7723 & 1.02 & 9.1 & 0.30 & 0.80 & 2.4 \\
& 248 & 7797 & 0.42 & 22.8 & 0.29 & 0.50 & 0.5 \\
& 252 & 7945 & 7.20 & 7.8 & 0.21 & 0.42 & 2.2 \\
\hline
\end{tabular}

hydroxy acids (Kolattukudy, 1980) while suberin is found in root material and contains large quantities of $\mathrm{C}_{22}$ and $\mathrm{C}_{24} \mathrm{\omega}$ hydroxy acids as well as $\mathrm{C}_{16} \omega$-hydroxy acid (Bull et al., 2000; Nierop et al., 2005). In contrast, $\alpha$-hydroxy acids are assumed to be of microbial origin (Fukushima et al., 1992). At Lz1120, $\omega$-hydroxy acids account for $90-100 \%$ of all hydroxy acids except in sample 505 (8.2 ka) where $58 \%$ of the hydroxy acids are $\alpha$-hydroxy acids. Apart from sample 505, the highest proportion of $\alpha$-hydroxy acids of $\sim 10 \%$ is found in the early Holocene sample 517 (8.5 ka). Notably, these two samples also contain small amounts of $\mathrm{C}_{18: 1} \alpha$-hydroxy acid $(0.05$ and $0.1 \%$ lipids, respectively). The presence of this labile compound and of $\mathrm{C}_{18: 1} \mathrm{FA}$ in these samples suggests in situ contribution from bacterial biomass. At site Co1202, $\alpha$-hydroxy acids were present in samples 246 and 248. Their proportion appears to be higher than in Lz1120. In sample 248 representing the $8.2 \mathrm{ka}$ event, they account for $41 \%$ of all hydroxy acids.

Shifts in the dominant chain lengths of the $\omega$-hydroxy acids suggest enhanced contribution of suberin-derived material in the glacial sample while increased proportions of cutin-derived material occur prior to the $8.2 \mathrm{ka}$ event at both sites.

\section{$3.7 \quad n$-alkanols}

The second-most abundant compound class in the investigated sediments are the $n$-alkanols (saturated alcohols) which make up $18-45 \%$ lipids at site Lz1120 and $26-56 \%$ lipids at Co1202, respectively. At both sites, the alkanol carbon numbers range from $n-\mathrm{C}_{12}$ to $n-\mathrm{C}_{32}$, but they are clearly dominated by the long-chain $n-\mathrm{C}_{24}$ and $n$ - $\mathrm{C}_{26}$ alkanols suggesting that the alkanol fraction is overwhelmingly of terrestrial origin.

The $n-\mathrm{C}_{24}$ alkanol is the major $n$-alkanol in Holocene samples at Lz1120 except in sample $517(8.5 \mathrm{ka})$ where the $n$ $\mathrm{C}_{28}$ alkanol dominates ( $25 \%$ of total $n$-alkanol fraction) and the surface sample where the $n-\mathrm{C}_{22}$ alkanol is most abundant (24\% of total $n$-alkanols). The $n-\mathrm{C}_{22}$ alkanol is also the dominant $n$-alkanol in the glacial sample (26\% of total $n$-alkanols). In both the surface and the glacial sample, the $n-\mathrm{C}_{22}$ alkanol appears superimposed as a single compound from a different source, onto the distribution pattern of higher plant-derived $n$-alkanols that are dominated by the $n-C_{26}$ alkanol. Volkman et al. (1999) found the $n$ $\mathrm{C}_{22}$ alkanol to dominate in eustigmatophytes, phototrophic marine and freshwater microalgae, while Jaffé et al. (2001) observed large amounts of this compound in epiphytes, in that case growing on sea grass. Since the surface sample reveals slightly higher contribution of short-chain $n-\mathrm{C}_{16}$ and $n-\mathrm{C}_{18}$ alkanols ( 7 and $2.5 \%$, respectively) as well as mono-unsaturated $(12 \%$ lipids $)$ and branched alkanoic acids $(2.8 \%$ lipids $)$, i.e. labile organic matter of algal and microbial sources, it appears most likely that the $n-\mathrm{C}_{22}$ alkanol in this sample mainly derives from relatively fresh/non-degraded lacustrine OM, which includes the remains of eustigmatophytes. In the glacial sample, however, the amounts of algalderived $n-\mathrm{C}_{16}$ and $n-\mathrm{C}_{18}$ alkanols are by far lower relative to the $n-\mathrm{C}_{22}$ alkanol than in the surface sample as is the concentration of short-chain $n$-alkanoic acids. This suggests a source for the $n-\mathrm{C}_{22}$ alkanols other than eustigmatophytes, perhaps epiphytes associated to macrophytes.

At site Co1202, the amount of short-chain $n-\mathrm{C}_{16}$ and $n$ $\mathrm{C}_{18}$ alkanols is $\sim 3-5$ times higher relative to the dominating $n-\mathrm{C}_{26}$ and $n-\mathrm{C}_{24}$ alkanols than at Lz1120 (excluding surface sample) suggesting that the contribution from autochthonous, lacustrine OM was higher. Nevertheless, the terrestrial long-chain alkanols clearly dominate.

\section{$3.8 \quad n$-alkanes}

$n$-alkanes represent a minor fraction of the total extractable lipids contributing an average of $2.1 \%$ to the TLE's from Holocene sediments of both cores. At Lz1120 their proportion is lowest in sample 517 from the early Holocene $(1.5 \%$ lipids $)$ and slightly higher in the surface sample and sample $483(7.5 \mathrm{ka}): 2.3 \%_{\text {lipids }}$ and $2.4 \%_{\text {lipids }}$, respectively. $n$-alkane concentrations are in a similar range at site Co1202 $(2.0-3.0 \%$ lipids $)$, with the maximum percentage observed in 
the sample representing the $8.2 \mathrm{ka}$ event. A noticeably higher percentage is observed only in the glacial sample of core Lz1120: $9.7 \%$ lipids. The $n$-alkanes detected in sediments of Lake Ohrid are mid- and long-chain odd-numbered compounds. The dominant compounds in most samples are the $n-\mathrm{C}_{29}$ and $n-\mathrm{C}_{31}$ alkanes with a significant contribution from $n-\mathrm{C}_{27}$ and minor proportions of $n-\mathrm{C}_{25}, n-\mathrm{C}_{23}$ and $n-\mathrm{C}_{21}$ alkanes. In the surface sample from Lz1120, the $n-\mathrm{C}_{21}$ alkane dominates accounting for $54 \%$ of the total $n$-alkane fraction. As for $n$-alkanoic acids, the chain length of $n$-alkanes indicates their major sources, with short-chain $n$-alkanes indicating algal input, mid-chain $n$-alkanes deriving from macrophytes and long-chain $n$-alkanes indicating terrestrial plant matter (Ficken et al., 2000). Based on this observation, Ficken et al. (2000) defined a proxy for contribution from emergent and submerged plants to lacustrine organic matter as $P_{\text {aq }}=\left(n-\mathrm{C}_{23}+n-\mathrm{C}_{25}\right) /\left(n-\mathrm{C}_{23}+n-\mathrm{C}_{25}+n-\mathrm{C}_{29}+n\right.$ $\left.\mathrm{C}_{31}\right)$. Accordingly, $P_{\mathrm{aq}}<0.1$ indicates pure terrestrial origin, $P_{\text {aq }}=0.1-0.4$ indicates dominating contribution from emergent plants and $P_{\mathrm{aq}}=0.4-1$ indicates dominating contribution from submerged plants. The $P_{\text {aq }}$ values range between 0.1 and 0.4 at both sites (Table 3) and suggest that most of the $n$-alkanes in Lake Ohrid sediments derive from terrestrial plant material with significant contribution from emergent plants, i.e. macrophytes.

\subsection{Sterols}

Sterols are far more abundant at Lz1120 than at Co1202. At Lz1120 they account for $11-26 \%$ of the total extracted lipids whereas they reach a maximum of only $10 \%$ at Co1202. Sterols are membrane lipids that occur ubiquitously in eukaryotic organisms (i.e. in animals, plants, fungi and microorganisms with a nucleus inside the cell membranes) but tend to be absent in prokaryotes (bacteria) with some exceptions such as methylotrophic bacteria (Volkman, 2005). The most abundant sterols in the Ohrid sediments are lanosterol $\left(4,4^{\prime}, 14 \alpha\right.$-trimethyl-5 $\alpha$-cholesta8,24-dien-3 $\beta$-ol), stigmastanol (24-ethyl- $5 \alpha(\mathrm{H})$-cholest-22en-3 $\beta$-ol), sitosterol (24-ethylcholest-5-en- $3 \beta$-ol), cholesterol (cholest-5-en- $3 \beta$-ol) and cholestanol $(5 \alpha(\mathrm{H})$-cholestan$3 \beta$-ol). At site Lz1120, these compounds account for all sterols in the glacial sample, though lanosterol was present only in trace amounts. Although the sterol fractions of the remaining samples at Lz1120 are dominated by these compounds as well, they also contain 7 to $26 \%$ of other sterols including dinosterol $(4 \alpha, 23,24$-trimethyl- $5 \alpha(\mathrm{H})$-cholest-22Een-3 $\beta$-ol) and two $\mathrm{C}_{30}$ 4-methyl stanols, one of which is probably dinostanol, that together account for $5-20 \%$ of the total sterols in samples 1 (surface), 483, 505 and 517. Furthermore, stigmasterol makes up 2-9\% of the sterols in almost all samples from Lz1120 except the glacial one $(643,18.9 \mathrm{ka})$, coprostanol $(5 \beta(\mathrm{H})$-cholestan-3 $\beta$-ol $)$ and epicoprostanol $(5 \beta(\mathrm{H})$-cholestan-3 3 -ol $)$ represent $6 \%$ in the surface sample and $1 \%$ in sample 517 and, finally, epicholestanol $(5 \alpha(\mathrm{H})$-cholestan-3 $\alpha$-ol) contributes $2-3 \%$ to the total sterols except in the glacial sample.

In contrast to site Lz1120, the dominant sterols at site Co1202 are the two $\mathrm{C}_{30}$ 4-methyl stanols that, together, account for $21-24 \%$ of the total sterols. Only in sample 252 sitosterol is more abundant (34\%). Second-most abundant compounds are stigmastanol in sample 246 (20\%) and cholesterol in sample 248 (19\%). Lanosterol is less abundant at this site and ranges from 7 to $13 \%$ of the total sterols, in a similar range to cholesterol and cholestanol (4-12\%). Dinosterol $(4 \alpha, 23,24$-trimethyl- $5 \alpha$-cholest- $22 E$-en-3 $\beta$-ol $)$ is present in all samples (4-7\%). Other than at site Lz1120, epicholestanol is present only in a very small amount $(\sim 1 \%$ of total lipids) in sample 248 while coprostanol, epicoprostanol and stigmasterol are below the detection limit in samples from Co1202.

Cholesterol and cholestanol are very common in living organisms and not very specific (e.g. Goosens et al., 1989). Cholesterol may derive from zooplankton such as ostracods or zoobenthos such as gastropods (Thiel et al., 1997), however, it is also found in dinoflagellates and some diatoms (Volkman, 1986). Sitosterol is the major sterol in higher plants but can also occur in diatoms and microalgae (Volkman, 1986, 2005). More specific are compounds like dinosterol and dinostanol that derive from dinoflagellates (e.g., Volkman, 1986; Mouradian et al., 2007).

Lanosterol is synthesised mainly by animals and fungi (Volkman, 2005). Like dinosterol it is also found, in small amounts, in dinoflagellates (Al-Mutlaq et al., 2008). Some sterols, however, have very specific sources. Coprostanol

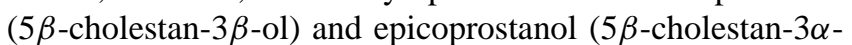
$\mathrm{ol}$ ), for example, are typically formed in the intestines of higher mammals including humans. Coprostanol is actually the dominant sterol in human faeces (Bull et al., 2002), while epicoprostanol is absent. Both compounds are therefore often used as indicators for manure or sewage contamination in soils and sediments (Sherwin et al., 1993; Cordeiro et al., 2008). We observed both coprostanol and epicoprostanol in the surface sample of Lz1120 where they make up $6 \%$ of the sterol fraction, thus reflecting modern inputs of faecal material from human and animal sources. Apart from the surface sample we found coprostanol in small amounts $(<1 \%$ of total sterols) in sample 517 which dates from the early Holocene. Epicoprostanol, in contrast, is absent in all other samples. However, epicholestanol was present in substantial amounts in almost every sample from site Lz1120 apart from the glacial sample (643) as well as in sample 248 from Co1202. This compound has been reported relatively rarely. However, Cordeiro et al. (2008) found it to be the second-most abundant faecal sterol after coprostanone and even more abundant than coprostanol in sediments of the Iguaçu River estuary (Brazil) and deduced that it is produced in-situ. Actually, epicholestanol is produced from cholesterol by bacteria under highly anoxic conditions (Robinson et al., 1984; Mermoud 
et al., 1985). Robinson et al. (1984) found high amounts of epicholestanol in Chlorobium, a phototrophic sulphideoxidising bacterium living near the sediment-water interface under anoxic conditions. In fact, those samples with low proportions of cholesterol also show low proportions of epicholestanol. The ratios of epicholestanol to cholestanol and of epicholestanol to coprostanol found in Lake Leman (Switzerland/France) by Mermoud et al. (1985) are very close to those found in Chlorobium by Robinson et al. (1984). This led Mermoud et al. (1985) to conclude that epicholestanol derives from anoxic bacteria contributing to the $\mathrm{OM}$ of surface sediments of Lake Leman. The ratios of epicholestanol to coprostanol in samples from Lz1120, where present, show similar values to those observed in Lake Leman (0.86 and 1.88 vs. 0.81 to 1.58 ) while the ratios of epicholestanol to cholestanol are slightly lower: $0.17-0.24$ in Lake Ohrid vs. $0.32-0.63$ in Lake Leman. Hence, anoxic bacteria such as Chlorobium could actually be considered as a source of epicholestanol and cholestanol in Lake Ohrid sediments. At least, these compounds are likely to share a common source since they show significant correlation in the Holocene sediments of Lz1120 ( $\left.r^{2}=0.97, n=5\right)$. Contribution from microbial biomass formed in situ is confirmed by the presence of branched FA (iso- and anteiso- $\mathrm{C}_{15} \mathrm{FA}$ ). Like epicholestanol, these are absent in the glacial sample and the samples from site Co1202.

\subsection{Others (triterpenoids, branched alkanols)}

Other quantified compounds include $17 \beta(\mathrm{H}), 21 \beta(\mathrm{H})$-bishomohopanoic acid and $17 \beta(\mathrm{H}), 21 \beta(\mathrm{H})$-bishomohopanol, both triterpenoids that derive directly from bacteriohopanepolyols (BHP's) of bacteria in sediments (e.g., Innes et al., 1997) and soils (e.g., Ries-Kautt and Albrecht, 1989). At site Lz1120, $17 \beta(\mathrm{H}), 21 \beta(\mathrm{H})$-bishomohopanoic acid accounts for up to $9 \%$ of the total extracted lipids, e.g., in sample 483 (7.5 ka). Lowest amounts of 2.5 and $2.8 \%$ lipids are observed in sample 505 (8.2 ka event) and in the glacial sample. The concentrations of $17 \beta(\mathrm{H}), 21 \beta(\mathrm{H})$-bishomohopanoic acid and $17 \beta(\mathrm{H}), 21 \beta(\mathrm{H})$-bishomohopanol do not correlate at site Lz1120 which suggests that they do not derive in similar proportions from the same source, i.e. from bacterial OM in sediments or in soils. The fact that other bacterial markers such as branched alkanoic acids do not correlate with $17 \beta(\mathrm{H}), 21 \beta(\mathrm{H})$-bishomohopanoic acid support the assumption that the latter mainly derives from soil bacteria. However, the lack of this correlation may also derive from different preservation potentials. In contrast, maximum values of $17 \beta(\mathrm{H}), 21 \beta(\mathrm{H})$-bishomohopanoic acid and $17 \beta(\mathrm{H}), 21 \beta(\mathrm{H})$ bishomohopanol do occur contemporaneously in sample 248 representing the $8.2 \mathrm{ka}$ event at site Co1202 suggesting they might derive from the same source in this case. The source could be soils since branched alkanoic acids are absent, although this might again result from a better preservation po- tential of the triterpenoids. The amounts of both compounds, however, are clearly lower than at site Lz1120 and range from 1 and $2 \%$ lipids, and 0.1 to $0.4 \%$ lipids, respectively.

Tetrahymanol (gammaceran-3 $\beta$-ol) which is found in ciliates (Harvey and McManus, 1991) as well as in the anaerobic phototrophic purple bacterium Rhodopseudomonas palustris (Kleemann et al., 1990) was also identified in the Lake Ohrid sediments. It has also been found in small amounts in a fern (Zander et al., 1969) and an anaerobic rumen fungus (Kemp et al., 1984). However, these are quite unlikely sources for tetrahymanol in the Lake Ohrid sediments. At site Lz1120, tetrahymanol makes up $0.2-1.9 \%$ of the total lipids with the lowest concentration in the glacial samples and the highest in the surface sample. At site Co1202, concentrations are clearly lower ranging from 0.04 to $0.13 \%$ lipids suggesting that either anaerobic phototrophic bacteria or ciliates were less important OM sources at this site.

$\beta$-Amyrin which derives from higher plants (Volkman, $2005)$ was detected in small amounts $(0.2-0.9 \%$ lipids $)$ in almost all samples except sample 252 (7.9 ka) from Co1202. As for $17 \beta(\mathrm{H}), 21 \beta(\mathrm{H})$-bishomohopanoic acid, highest concentrations are present in the samples representing the $8.2 \mathrm{ka}$ event. Furthermore, we found iso- and anteiso-branched $\mathrm{C}_{15}$ alkanols in samples 1 (surface), 399 (5.3 ka) and 483 (7.5 ka) as well as branched $\mathrm{C}_{17}$ alkanol (iso and anteiso) in the surface sample of Lz1120. The $\mathrm{C}_{15}$ compounds derive from bacteria (Cranwell, 1980) and a branched $\mathrm{C}_{17}$ alkanol has been identified in microbial mats from the Florida Everglades (Thiel et al., 1997). None of these compounds, however, were present in the samples from site Co1202.

\section{Discussion}

The results of our study of extractable lipid biomarkers in Lake Ohrid sediments have revealed a number of compositional differences between the two sites and also between samples of different levels of OM degradation (surface sample vs. the rest) and from different climatic conditions (Holocene vs. glacial and presumed $8.2 \mathrm{ka}$ event). For a reconstruction of environmental changes based on sedimentary OM composition, the detection of changes in the contributions from various sources is crucial. One problem in this context is the preservation potential of the sourcespecific compounds which can differ considerably. For example, unsaturated compounds are generally more labile than their saturated counterparts and branched compounds more labile than straight-chain compounds (Haddad et al., 1992). Equally important, however, is the matrix in which the biomarkers are incorporated at the time of supply to the sedimentary system as well as the sedimentary regime itself, i.e. whether anoxic, suboxic or oxic conditions prevail, since they determine the mode of microbial consumption of the sedimentary OM. Long-chain terrestrial fatty acids and alcohols, for example, are per se not more resistant towards 
microbial attack than short-chain autochthonous alkanoic acids and alkanols in an aquatic environment. However, they occur in plant tissues or particles largely consisting of relatively recalcitrant organic substances such as lignin or cellulose that usually have already been under microbial attack and, hence, represent the debris from terrestrial degradation (e.g., Meyers, 1997). They can also be strongly associated with clay minerals as a result of soil formation processes, which equally makes them relatively inaccessible for microbes in the water column and in the sediments and thus increases their preservation potential compared to easily accessible autochthonous OM (Goosens et al., 1989; Haddad et al., 1992; Meyers and Ishiwatari, 1993). Another factor controlling the preservation potential of sedimentary OM is the availability of oxygen. Oxygen-depleted (suboxic) or oxygen-free (anoxic) conditions increase the OM preservation potential. Precipitation of sulphides is a common side effect of OM degradation under anoxic conditions. The finding that TOC/TS ratios at Co1202 are lower than at site Lz1120 might result from the fact that Co1202 is situated in deeper water just below the summer thermocline (Matzinger et al., 2007) that is less frequently mixed and hence exhibits greater oxygen depletion. Finally, we also have to consider variable degrees of degradation for the terrestrial organic input for a correct interpretation of the biomarker data. Terrestrial OM is delivered as relatively fresh plant litter from various types of vegetation, e.g., deciduous/pine forests or grasslands, or as soil OM in a whole range of possible stages of degradation.

\subsection{Evidence for soil organic matter supply}

There is evidence for the contribution of soil OM to the sediments of Lake Ohrid when considering the fact that soil OM has often been found depleted in $n$-alkanoic acids relative to $n$-alkanols and hydroxy acids (e.g., Bull et al., 2000; Nierop et al., 2005, 2009). While terrestrial $n$-alkanols are present throughout the cores as a major organic fraction, the proportion of terrestrially derived $n$-alkanoic acids varies strongly. In those samples where terrestrial $n$-alkanols are dominant, i.e. in the glacial sample and the samples representing the $8.2 \mathrm{ka}$ event from both sites, long-chain terrestrially derived $n$-alkanoic acids $\left(>\mathrm{C}_{24}\right)$ are almost absent (Fig. $\left.4 \mathrm{~b}, \mathrm{c}\right)$. This suggests two distinct terrestrial OM sources, one of which is strongly depleted in long-chain $n$-alkanoic acids relative to long-chain $n$-alkanols and therefore most likely represents soil OM. This depletion of terrestrial $n$-alkanoic acids significantly lowers the ratio of the bulk $n$-alkanoic acids over $n$-alkanols (FA/OH, Table 3). Further evidence for the contribution of soil $\mathrm{OM}$ comes from the bimodal distribution of $\mathrm{C}_{16}, \mathrm{C}_{22}$ and $\mathrm{C}_{24} \omega$-hydroxy acids. Such a pattern has been described for lake sediments (Goosens et al., 1989; Fukushima et al., 1992), but also for soils (Nierop et al., 2005). Fukushima et al. (1992) regard plant matter and eroded soils as the source at least for the long-chain hydroxy acids. With the exception of the surface sample, the
$\mathrm{C}_{22}$ and $\mathrm{C}_{24} \omega$-hydroxy acid concentrations correlate closely at Lz1120 $\left(r^{2}=0.99 ; n=5\right)$, whereas the $\mathrm{C}_{16} \omega$-hydroxy acid does not. This suggests that $\mathrm{C}_{22}$ and $\mathrm{C}_{24} \omega$-hydroxy acids share a common source that might not necessarily be the same as that of the $\mathrm{C}_{16} \omega$-hydroxy acid. Based on their investigations of soil OM profiles and plant litter, Nierop et al. (2009) suggest that higher ratios of $\mathrm{C}_{22} / \mathrm{C}_{16} \omega$-hydroxy acid reflect enhanced proportions of suberin-derived root material relative to cutin-derived aerial plant material, i.e. plant litter. They also found that a substantial proportion of soil $\mathrm{OM}$ derives from root material. Slightly higher values of the $\mathrm{C}_{22} / \mathrm{C}_{16} \omega$-hydroxy acid ratio at Lz1120 compared to Co1202 would thus indicate higher soil OM proportions relative to plant litter. It would also suggest that soil OM proportions are highest during the glacial and elevated in the surface sample and sample 399 from the mid-Holocene (5.3 ka). Soil OM is likely to be depleted overall in extractable lipids and enriched in more stable OM and black carbon. Since the glacial sample shows the lowest amount of extractable lipids relative to the TOC it can be assumed that high levels of soil OM contribute to the bulk sedimentary OM.

According to the above observations of $n$-alkanol $/ n$ alkanoic acid and hydroxy acids distributions, soil OM input is generally higher at Lz1120 compared to Co1202 since all samples from the southern site reveal higher proportions of long-chain $n$-alcohols and hydroxy acids. It also appears to be higher in the samples from the $8.2 \mathrm{ka}$ event and the glacial. However, this does not necessarily indicate higher soil erosion during these periods. According to a number of paleoclimatological studies regional climate was considerably drier during the glacial and the $8.2 \mathrm{ka}$ event (Bordon et al., 2009; Fouache et al., 2010). If the long-chain $n$-alkanoic acids derive primarily from less degraded plant litter it is rather likely that their contribution was diminished in response to precipitation-controlled changes in the vegetation cover and lower biomass productivity. Accordingly, concentrations of $n$-alkanoic acids per gram sediment at both sites are lower by a factor of 13 on average in the samples representing the $8.2 \mathrm{ka}$ event, relative to the previous and the following samples. Concentrations of $n$-alkanols, however, remain roughly the same. This implies that mineral and soil OM supplies are associated and depend on the same transport mechanism, i.e. surface run-off. Although precipitation was generally reduced, soil erosion rates might have been increased due to higher soil exposure and lower stabilising soil moisture, thus, compensating for lower run-off and creating a rather constant background signal of soil supply through the $8.2 \mathrm{ka}$ event at both sites. Greater sedimentation rates and soil OM contributions at site Lz1120 might be related to the proximity of the Cerava River mouth. Although its modern discharge is very small $\left(0.2 \mathrm{~m}^{3} \mathrm{~s}^{-1}\right)$ compared to the total input from rivers and streams to the lake $\left(8.9 \mathrm{~m}^{3} \mathrm{~s}^{-1}\right.$; Matzinger et al., 2006) the river might have exported very different amounts of mineral and soil organic matter at times depending on the precipitation intensity. The discharge of the karst springs of 
Tushemisht and Sveti Naum, which are responsible for about a quarter of the total inflow into Lake Ohrid $\left(10 \mathrm{~m}^{3} \mathrm{~s}^{-1}\right)$, responded directly to changes in precipitation and is likely to have affected the availability of nutrients such as phosphorus for endemic phytoplankton species, although in the immediate surroundings, only (Matzinger et al., 2006). However, the karst springs do not deliver any significant amounts of minerals and soil OM.

\subsection{Evidence for vegetation changes}

The changing predominance of long-chain terrestriallyderived $n$-alkanols, $n$-alkanoic acids and $n$-alkanes in the sediments at both sites can potentially be ascribed to the type of vegetation from which they derive. Results of studies comparing plant matter and soil OM from different types of vegetation by van Bergen et al. (1997, 1998), Bull et al. (2000) and Nierop et al. (2005) suggest that $n$-alkanols of leaf tissue from trees are dominated by the $n-\mathrm{C}_{24}$ alkanol whereas those derived from grasses are dominated by the $n-\mathrm{C}_{26}$ or $n-\mathrm{C}_{28}$ compounds. Accordingly, contribution of $n$-alkanols from grasses and herbs dominates in the early Holocene samples and the samples representing the $8.2 \mathrm{ka}$ event from both sites (Lz1120: 517, 505, Co1202: 252, 248), while $n$-alkanols from trees dominate in the remaining samples except the surface sample and the glacial sample which are dominated by the $n-\mathrm{C}_{22}$ alkanol. However, the $n$-alkanol distributions of these two samples are, notably, almost bimodal and show the $n-\mathrm{C}_{26}$ alkanol as the second most important compound also suggesting significant contribution from grasses and herbs. This finding is largely consistent with the pollen record of Lz1120 (Wagner et al., 2009) which indicates strongly increased proportions of pollen from herbs during the glacial and after $3.5 \mathrm{ka}$ and slightly increased proportions for the $8.2 \mathrm{ka}$ event.

So far, no general pattern has emerged for the distribution of long-chain $n$-alkanoic acids in relation to vegetation types. The low $\mathrm{CPI}_{\mathrm{H}}$ value for the long-chain $n$-alkanoic acids of the glacial sample could imply that the $n$-alkanoic acids experienced some degradation and, hence, may partly derive from soils. However, other samples with indication for higher soil input, namely the two samples representing the $8.2 \mathrm{ka}$ event at both sites, do not show such low values. Alternatively, the low $\mathrm{CPI}_{\mathrm{H}}$ value of the glacial sample could result from relatively enhanced amounts of reed-derived material. Matsudo and Koyama (1977) report low $\mathrm{CPI}_{\mathrm{H}}$ values for tissue samples of leaves (0.9), stems (2.0) and dead leaves (1.6) of the common reed, Phragmites communis, from the littoral zones of Lake Suwa (Japan). This interpretation suggests increased contributions from the littoral zones of Lake Ohrid relative to terrestrial biomass production during the glacial and would be supported by the high amount of $n$ - $\mathrm{C}_{22}$ alkanol derived from epiphytes associated to macrophytes. Currently, annual productivity of epiphytic algae is in fact four times higher than phytoplankton productivity in the lit- toral zones of Lake Ohrid with epiphytes thriving particularly in Phragmites stands (Allen and Ocevski, 1981). Under dry climate conditions, when productivity on land and in the open lake waters was hampered due to reduced precipitation and diminished supply of nutrients and dissolved organic carbon required for phytoplankton productivity in Lake Ohrid (Allen and Ocevski, 1977), the littoral zones may have become a relatively more productive element of the ecosystem. This conclusion is supported by the $P_{\text {aq }}$ value that is slightly higher for the glacial sample $(0.24$, Table 3$)$ than for the Holocene samples (0.14-0.18) apart from the surface sample (0.32) and suggests higher contributions from emergent plants such as reeds. However, the differences are marginal and may as well reflect natural variability.

The described variability in chain-length distributions of $n$-alkanols and $n$-alkanoic acids suggests changing contributions from different types of vegetation, including macrophytes in the littoral zone. The data are complex, but illustrate the potential of biomarkers in the reconstructions of ecosystem changes. However, as for the reconstruction of soil inputs, this approach requires a sound knowledge of the possible sources and the mechanisms controlling the supply of specific biomarkers and, thus, needs high-resolution investigations of dynamic climate stages triggering extensive readjustments of the ecosystem.

\subsection{Further implications from sterol and triterpenoid composition}

Many of the sterols identified in Lake Ohrid sediment samples such as cholesterol, lanosterol or sitosterol are not very specific. However, they can still indicate ecosystem changes when investigated in relation to each other or to biomarkers of other compound classes. Generally, terrestrial sterols appear to have a much greater preservation potential than their planktonic counterparts (Volkman, 1986).

Lanosterol, one of the most abundant sterols at site Lz1120, is synthesised in the terrestrial realm by fungi (e.g., Volkman, 2005 and references therein) but may also derive from dinoflagellates (Al-Mutlaq et al., 2008). However, it does not show any correlation with dinosterol and dinostanol concentrations (either isomer). In contrast, there is a significant linear correlation $\left(r^{2}=0.87, n=5\right)$ between lanosterol and the higher plant-derived $\beta$-amyrin in the Holocene samples from Lz1120. Since lanosterol appears to correlate with the terrestrial compound only, we may assume a predominantly fungal origin. Consequently, it is not surprising to find only traces of lanosterol in the glacial sample when fungal activity was either suppressed by the considerably drier conditions or the substrate, i.e. humus, was not abundant. Also, bacterially-derived $17 \beta(\mathrm{H}), 21 \beta(\mathrm{H})$ bishomohopanoic acid shows lowest concentrations in the glacial sample at Lz1120 as well as in sample 505 from the $8.2 \mathrm{ka}$ event, suggesting that bacterial activity was reduced under drier and cooler conditions, as well. In the 
remaining samples, $17 \beta(\mathrm{H}), 21 \beta(\mathrm{H})$-bishomohopanoic acid correlates well with lanosterol and $\beta$-amyrin $\left(r^{2}=0.95\right.$ in both cases, $n=4)$. These relations suggest that lanosterol, $\beta$ amyrin and $17 \beta(\mathrm{H}), 21 \beta(\mathrm{H})$-bishomohopanoic acid at times either share a common source or that their contemporaneous supply is controlled by the same mechanism, at least under relatively humid climate conditions. It is not unlikely that all of these compounds are part of a terrestrial $\mathrm{OM}$ fraction that combines plant matter ( $\beta$-amyrin), compounds synthesised by fungi (lanosterol) and bacterial markers $(17 \beta(\mathrm{H}), 21 \beta(\mathrm{H})$-bishomohopanoic acid), i.e. plant litter decomposing under moist conditions as they prevail, e.g., in humus layers of the top soils. The supply of this specific combination would be restricted to humid climate conditions and the presence of substantial soils for fungi and bacteria to thrive. Without these factors, either the supply of lanosterol from fungi or of $17 \beta(\mathrm{H}), 21 \beta(\mathrm{H})$-bishomohopanoic acid from bacteria should be reduced and only $\beta$-amyrin may be delivered through plant litter from a readjusted (less productive) vegetation cover. This scenario can be observed in the glacial sample. In case of sample 505 from the $8.2 \mathrm{ka}$ event, in contrast, the climate was drier but soils that were built up during the early Holocene were probably still present although their microbial turn-over may have been reduced. Accordingly, we find a high concentration of lanosterol but a considerably lower concentration of $17 \beta(\mathrm{H}), 21 \beta(\mathrm{H})$ bishomohopanoic acid comparable to that of the glacial sample. This scenario, however, requires fungally-derived lanosterol to be better preserved in the top soils than bacterialderived $17 \beta(\mathrm{H}), 21 \beta(\mathrm{H})$-bishomohopanoic acid, an assumption for which there is no evidence available.

In a similar way we can relate the presence of some sterol markers to proxies such as the TOC/TS ratio. Notably, epicholestanol occurs at site Co1202 only in the sample with the lowest TOC/TS ratio (11), i.e. in sample 428 representing the $8.2 \mathrm{ka}$ event. At site Lz1120, epicholestanol is present in all samples apart from the glacial one and TOC/TS ratios are considerably higher. If higher TOC/TS ratios mainly reflect higher input of terrestrial organic carbon and nutrients, oxygen consumption in the surface waters of the southern areas of Lake Ohrid might have been more efficient, particularly during humid climate stages, resulting in a shallower chemocline in the catchment of Lz1120. There, oxygen-depleted conditions were apparently always established within the photic zone, except during the glacial, supporting phototrophic sulphide-oxidisers such as Chlorobium that synthesise epicholestanol. Remarkably, epicholestanol concentrations correlate with those of tetrahymanol at Lz1120 $\left(r^{2}=\right.$ $0.96, n=5)$ with the exception of sample $483(7.5 \mathrm{ka})$ where the content of epicholestanol is particularly high. Tetrahymanol has been associated with oxic/anoxic boundary layers in freshwater systems where ciliates feed on phototrophic anaerobic bacteria (Sinninghe Damsté et al., 1995; Guhl and Finlay, 1993) some of which actually produce tetrahymanol themselves (e.g., Rhodopseudomonas palustris, Klee- mann et al., 1990). At Co1202, in contrast, the chemocline might have been too deep for phototrophic anaerobic bacteria to thrive except, it appears, during the drier conditions of the $8.2 \mathrm{ka}$ event. A possible explanation for this seemingly opposing pattern could be that phototrophic sulphur bacteria could live in the oxygen-depleted waters at and below the (deeper) chemocline at site Co1202 only at times of increased light penetration, e.g., times of reduced terrestrial run-off and clearer surface water. At least ciliates, in contrast, seem to have occured at Co1202 throughout as indicated by tetrahymanol in all samples from this site and, apparently, thrive independently from the presence of phototrophic anaerobic bacteria. Notably, though, the amount of tetrahymanol from ciliates at Co1202 is highest relative to the total lipid content in the only sample that also contains epicholestanol from phototrophic anaerobic bacteria. Thus, our results offer the perspective of reconstructing past changes in lake chemistry and the variable levels of the chemocline based on a specific sterol marker, epicholestanol, with support from its correlation with tetrahymanol.

The identification of coprostanol in sample 517 from the early Holocene $(8.5 \mathrm{ka})$ is quite remarkable since it possibly indicates the presence of some significant human population. Alternative sources of coprostanol could be faeces of pigs or herbivores (e.g., cattle, sheep, goats) although its concentration is much lower in the animal faeces than in human faeces (Bull et al., 2002). It is worth noting, though, that pigs, cows and ovicaprids (sheep, goats) had already been domesticated and were an important resource for the first settled societies in the Balkans since about $8.5 \mathrm{ka}$ (Bailey, 2000), hence, could have been associated to human communities as well. However, to our knowledge substantial human settlements are not documented until the onset of the Neolithic, i.e. after the $8.2 \mathrm{ka}$ event, in the neighbouring Korça Basin (Fouache et al., 2010). Although intriguing, the occurrence of coprostanol therefore needs systematic tracking in highresolution studies.

\section{Conclusions}

Our study presents a first inventory of lipid biomarkers present in total lipid extracts from Holocene and glacial sediments of ancient Lake Ohrid. A small set of samples from two sites, Lz1120 near the southern shoreline and Co1202 near the eastern shoreline, has been investigated. Gross composition of major lipid compounds reveals significant differences between the sites reflecting the different settings in their individual catchments, i.e. morphology and associated drainage. Significant amounts of labile unsaturated lipids were only found in the surface sample reflecting effective degradation of these compounds with depth. Changes in the proportions of long-chain terrestrial $n$-alkanoic acids and $n$-alkanols and shifts in chain length of the dominant $\omega$-hydroxy acids indicate higher proportions of soil-derived 
OM at Lz1120 than at site Co1202. The relative amount of soil OM appeared to increase under the dry climate conditions of the $8.2 \mathrm{ka}$ event at both sites. The ratio of $n$-alkanoic acids to $n$-alkanols (FA/OH) may provide a tool to quickly identify phases of reduced terrestrial productivity and relatively increased soil OM supply for future studies of Lake Ohrid's sedimentary archive. Changes in the chain-length of the dominating long-chain-terrestrial $n$-alkanols, particularly the switch from $n-\mathrm{C}_{26}$ and $n-\mathrm{C}_{28}$ alkanol to $n-\mathrm{C}_{24}$ alkanol after the $8.2 \mathrm{ka}$ event, probably reflect changes in the vegetation cover from vegetation with considerable proportions of grass and herbs to mostly trees. Higher input from the littoral zones relative to the overall productivity of the ecosystem is indicated for the glacial sample by a combination of low $\mathrm{CPI}_{\mathrm{H}}$ value, increased amounts of $n-\mathrm{C}_{22}$ alkanol from epiphytes and a slightly higher $P_{\text {aq }}$ value. Notably, the $n-C_{22}$ alkanol detected in the surface sediment appears to derive from a different major source, i.e. eustigmatophytes, illustrating the necessity of multi-proxy approaches to correctly identify the source of certain biomarkers. Epicholestanol deriving from anaerobic phototrophic bacteria as well as tetrahymanol from ciliates that often feed on bacteria along oxic/anoxic boundary layers both have been identified and, when combined, could provide a tool to detect vertical shifts of the chemocline. Finally, we found evidence for human and/or animal faeces (pigs, herbivores) through the detection of coprostanol in the surface sample, where it could be expected, but also in a sample from the early Holocene where it might indicate the early presence of settled human communities and domesticated animals. We could thus document the effects of spatial and temporal changes in soil OM supply and of increased contribution from the littoral zone, possible changes in vegetation, anoxia in the photic zone and anthropogenic influence on the composition of total lipid extracts from ancient Lake Ohrid. We believe that lipid biomarkers can provide powerful tools to investigate various aspects of environmental change in detail in future high-resolution studies of Lake Ohrid's outstanding sedimentary archive.

\section{Supplementary material related to this article is available online at: http://www.biogeosciences.net/7/3473/2010/ bg-7-3473-2010-supplement.pdf.}

Acknowledgements. We would like to thank Rudolf Jaffé, Philip Meyers and an anonymous reviewer for their much appreciated comments on an earlier version of this manuscript. We are also grateful to A. Thompson, N. Mantke and F. Boxberg for technical support in the laboratories at Liverpool and Cologne Universities. J. H. wishes to thank the University of Liverpool for support to carry out the lipid analyses. Field work and elemental analyses were funded by the German Research Foundation (DFG).

Edited by: T. Wilke

\section{References}

Ahlgren, G., Gustafsson, I.-B., and Boberg, M.: Fatty acid content and chemical composition of freshwater microalgae, J. Phycol., 28, 37-50, 1992.

Albrecht, C. and Wilke, T.: Ancient Lake Ohrid: biodiversity and evolution, Hydrobiologia, 615, 113-140, 2008.

Allen, H. L. and Ocevski, B. T.: Comparative primary productivity of algal epiphytes on three species of macrophyte in the littoral zone of Lake Ohrid, Yugoslavia, Holarctic Ecol., 4, 155-160, 1981.

Allen, H. L. and Ocevski, B. T.: Limnological studies in a large, deep, oligotrophic lake (Lake Ohrid, Yugoslavia). A summary of nutritional radiobioassay responses of the pelagial phytoplankton, Hydrobiologia, 53, 49-54, 1977.

Al-Mutlaq, K. F., Laurel, J., Standley, L. J., and Simoneit, B. R. T.: Composition and sources of extractable organic matter from a sediment core in Lake Kivu, East African rift valley, Appl. Geochem., 23, 1023-1040, 2008.

Amblès, A., Jambu, P., Parlanti, E., Joffre, J., and Riffe, C.: Incorporation of natural monoacids from plant residues into an hydromorphic forest podzol, Eur. J. Soil Sci., 45, 115-182, 1994.

Bailey, D. W.: Balkan prehistory, Routledge, London, 131-139, 2000.

Belmecheri, S., Namiotko, T., Robert, C., von Grafenstein, U., and Danielopol, D. L.: Climate controlled ostracod preservation in Lake Ohrid (Albania, Macedonia), Palaeogeogr. Palaeocl., 277, 236-245, 2009.

Bobbie, R. J. and White, D. C.: Characterization of benthic microbial community structure by high-resolution gas chromatography of fatty acid methyl esters, Appl. Environ. Microb., 39, 12121222, 1980.

Bordon, A., Peyron, O., Lézine, A.-M., Brewer, S., and Fouache, E.: Pollen-inferred Late-Glacial and Holocene climate in southern Balkans (Lake Maliq), Quatern. Int., 200, 19-30, 2009.

Bourbonniere, R. A. and Meyers, P. A.: Sedimentary geolipid records of historical changes in the watersheds and productivities of Lakes Ontario and Erie, Limnol. Oceanogr., 41, 352-359, 1996.

Brewer, S., Cheddadi, R., de Beaulieu, J. L., Reille, M., and data contributors: The spread of deciduous Quercus throughout Europe since the last glacial period, Forest Ecol. Manag., 156, 2748, 2002.

Bull, I. D., Lockheart, M. J., Elhmmali, M. M., Roberts, D. J., and Evershed, R. P.: The origin of faeces by means of biomarker detection, Environ. Int., 27, 647-654, 2002.

Bull, I. D., van Bergen, P. F., Nott, C. J., Poulton, P. R., and Evershed, R. P.: Organic geochemical studies of soils from the Rothamsted classical experiments $-\mathrm{V}$. The fate of lipids in different long-term experiments, Org. Geochem., 31, 389-408, 2000.

Cordeiro, L. G. S. M., Carreira, R. S., and Wagener, A. L. R.: Geochemistry of fecal sterols in a contaminated estuary in southeastern Brazil, Org. Geochem., 39, 1097-1103, 2008.

Cranwell, P.: Branched/cyclic alkanols in lacustrine sediments (Great Britain): recognition of iso- and anteiso-branching and stereochemical analysis of homologous alkan-2-ols, Chem. Geol., 30, 15-26, 1980.

Cranwell, P. A.: Branched-chain and cyclopropanoid acids in a recent sediment, Chem. Geol, 11, 307-313, 1973.

Ficken, K. J., Wooller, M. J., Swain, D. L., Street-Perrott, F. A., 
and Eglinton, G.: Reconstruction of a subalpine grass-dominated ecosystem, Lake Rutundu, Mount Kenya: a novel multi-proxy approach, Palaeogeogr. Palaeocl., 177, 137-149, 2002.

Ficken, K. J., Li, B., Swain, D. L., and Eglinton, G.: An $n$-alkane proxy for the sedimentary input of submerged/floating freshwater aquatic macrophytes, Org. Geochem., 31, 745-749, 2000.

Fouache, E., Desruelles, S., Magny, M., Bordon, A., Oberweiler, C., Coussot, C., Touchais, G., Lera, P., Lézine, A.-M., Fadin, L., and Roger, R.: Palaeogeographical reconstructions of Lake Maliq (Korça Basin, Albania) between 14000 BP and 2000 BP, J. Archaeol. Sci., 37, 525-535, 2010.

Fukushima, K., Kondo, H., and Sakata, S.: Geochemistry of hydroxy acids in sediments $-\mathrm{I}$. Some freshwater and brackish water lakes in Japan, Org. Geochem., 18, 913-922, 1992.

Goosens, H., Düren, R. R., de Leeuw, J. W., and Schenck, P. A.: Lipids and their mode of occurrence in bacteria and sediments - II. Lipids in the sediment of a stratified freshwater lake, Org. Geochem., 14, 27-41, 1989.

Guhl, B. E. and Finlay, B. J.: Anaerobic predatory ciliates track seasonal migrations of planktonic photosynthetic bacteria, FEMS Microbiol. Lett., 107, 313-316, 1993.

Haddad, R. I., Martens, C. S., and Farrington, J. W.: Quantifying early diagenesis of fatty acids in a rapidly accumulating coastal marine sediment, Org. Geochem., 19, 205-216, 1992.

Hartmann, M.-A.: Plant sterols and the membrane environment, Trends Plant Sci., 3, 170-175, 1998.

Harvey, H. R. and McManus, G. B.: Marine ciliates as a widespread source of tetrahymanol and hopan- $3 \beta$-ol in sediments, Geochim. Cosmochim. Ac., 55, 3387-3390, 1991.

Innes, H. E., Bishop, A. N., Head, I. M., and Farrimond, P.: Preservation and diagenesis of hopanoids in Recent lacustrine sediments of Priest Pot, England, Org. Geochem., 26, 565-576, 1997.

Jaffé, R., Mead, R., Hernandez, M. E., Peralba, M. C., and DiGuida, O. A.: Origin and transport of sedimentary organic matter in two subtropical estuaries: a comparative, biomarker-based study, Org. Geochem., 32, 507-526, 2001.

Kattner, G., Gercken, G., and Hammer, K. D.: Development of lipids during a spring bloom in the northern North Sea - II. Dissolved lipids and fatty acids, Mar. Chem., 14, 163-173, 1983.

Kemp, P., Lander, D. J., and Orpin, C. G.: The lipids of the rumen fungus Piromonas communis, J. Gen. Microbiol., 130, 27-37, 1984.

Kleemann, G., Poralla, K., Englert, G., Kjøsen, H., Liaaen-Jensen, S., Neunlist, S., and Rohmer, M.: Tetrahymanol from the phototrophic bacterium Rhodopseudomonas palustris: first report of a gammacerane triterpene from a prokaryote, J. Gen. Microbiol., 136, 2551-2553, 1990.

Kolattukudy, P. E.: Biopolyester membranes of plants: cutin and suberin, Science, 208, 990-1000, 1980.

Matsudo, H. and Koyama, T.: Early diagenesis of fatty acids in lacustrine sediments - II. A statistical approach to changes in fatty acid composition from recent sediments and some source materials, Geochim Cosmochim. Ac., 41, 1825-1834, 1977.

Matzinger, A., Schmid, M., Veljanoska-Sarafiloska, E., Patceva, S., Guseska, D., Wagner, B., Müller, B., Sturm, M., and Wüest, A.: Eutrophication of ancient Lake Ohrid: global warming amplifies detrimental effects of increased nutrient inputs, Limnol. Oceanogr., 52, 338-353, 2007.
Matzinger, A., Jordanoski, M., Veljanoska-Sarafiloska, E., Sturm, M., Müller, B., and Wüest, A.: Is Lake Prespa jeopardizing the ecosystem of ancient Lake Ohrid?, Hydrobiologia, 553, 89-109, 2006.

Mermoud, F., Gülaçar, F. O., and Buchs, A.: $5 \alpha(\mathrm{H})$-Cholestan-3 $\alpha$ ol in sediments: Characterization and geochemical significance, Geochim. Cosmochim. Ac., 49, 459-462, 1985.

Meyers, P. A.: Organic geochemical proxies of paleoceanographic, paleolimnologic, and paleoclimatic processes, Org. Geochem., 27, 213-250, 1997.

Meyers, P. A. and Ishiwatari, R.: Lacustrine organic geochemistry - an overview of indicators of organic matter sources and diagenesis in lake sediments, Org. Geochem., 20, 867-900, 1993.

Mouradian, M., Panetta, R. J., de Vernal, A., and Gélinas, Y.: Dinosterols or dinocysts to estimate dinoflagellate contributions to marine sedimentary organic matter?, Limnol. Oceanogr., 52, 2569-2581, 2007.

Nierop, K. G. J. and Jansen, B.: Extensive transformation of organic matter and excellent lipid preservation at the upper, superhumid Guandera páramo, Geoderma, 151, 357-369, 2009.

Nierop, K. G. J., Naafs, D. F. W., and van Bergen, P. F.: Origin, occurrence and fate of extractable lipids in Dutch coastal dune soils along a pH gradient, Org. Geochem, 36, 555-566, 2005.

Ries-Kautt, M. and Albrecht, P.: Hopane-derived triterpenoids in soils, Chem. Geol., 76, 143-151, 1989.

Robinson, N., Cranwell, P. A., Finlay, B. J., and Eglinton, G.: Lipids of aquatic organisms as potential contributors to lacustrine sediments, Org. Geochem., 6, 143-152, 1984.

Sherwin, M. R., Vanvleet, E. S., Fossato, V. U., and Dolci, F.: Coprostanol ( $5 \beta$-cholestan-3- $\beta$-ol) in lagoonal sediments and mussels of Venice, Italy, Mar. Pollut. Bull., 26, 501-507, 1993.

Sinninghe Damsté, J. S., Kenig, F., Koopmans, M. P., Köster, J., Schouten, S., Hayes, J. M., and de Leeuw, J. W.: Evidence for gammacerane as an indicator of water column stratification, Geochim. Cosmochim. Ac., 59, 1895-1900, 1995.

Thiel, V., Merz-Preiss, M., Reitner, J., and Michaelis, W.: Biomarker studies on microbial carbonates: extractable lipids of a calcifying cyanobacterial mat (Everglades, USA), Facies, 36, 163-172, 1997.

van Bergen, P. F., Nott, C. J., Bull, I. D., Poulton, P. R, and Evershed, R. P.: Organic geochemical studies of soils from the Rothamsted Classical Experiments - IV. Preliminary results from a study of the effect of soil $\mathrm{pH}$ on organic matter decay, Org. Geochem., 29, 1779-1795, 1998.

van Bergen, P. F., Bull, I. D., Poulton, P. R., and Evershed, R. P.: Organic geochemical studies of soils from the Rothamsted Classical Experiments - I. Total lipid extracts, solvent insoluble residues and humic acids from Broadbalk Wilderness, Org. Geochem., 26, 117-135, 1997.

Vogel, H., Wagner, B., Zanchetta, G., Sulpizio, R., and Rosén, P.: A paleoclimate record with tephrochronological age control for the last glacial-interglacial cycle from Lake Ohrid, Albania and Macedonia, J. Paleolimnol., 44, 295-310, doi:10.1007/s10933009-9404-x, 2010a.

Vogel, H., Zanchetta, G., Sulpizio, R., Wagner, B., and Nowaczyk, N.: A tephrostratigraphic record for the last glacial-interglacial cycle from Lake Ohrid, Albania and Macedonia, J. Quaternary Sci., 25, 320-338, 2010b.

Vogel, H., Wessels, M., Albrecht, C., Stich, H.-B., and Wagner, 
B.: Spatial variability of recent sedimentation in Lake Ohrid (Albania/Macedonia) - a complex interplay of natural and anthropogenic factors and their possible impact on biodiversity patterns, Biogeosciences Discuss., 7, 3911-3930, doi:10.5194/bgd7-3911-2010, 2010c.

Volkman, J. K.: Sterols and other triterpenoids: source specificity and evolution of biosynthetic pathways, Org. Geochem., 36, 139-159, 2005.

Volkman, J. K., Barrett, S. M., and Blackburn, S. I.: Eustigmatophyte microalgae are potential sources of $\mathrm{C}_{29}$ sterols, $\mathrm{C}_{22}-$ $\mathrm{C}_{28} n$-alcohols and $\mathrm{C}_{28}-\mathrm{C}_{32} n$-alkyl diols in freshwater environments, Org. Geochem. 30, 307-318, 1999.

Volkman, J. K.: A review of sterol markers for marine and terrigenous organic matter, Org. Geochem., 9, 83-99, 1986.
Wagner, B., Reicherter, K., Daut, G., Wessels, M., Matzinger, A., Schwalb, A., Spirkovski, Z., and Sanxhaku, M.: The potential of Lake Ohrid for long-term palaeoenvironmental reconstructions, Palaeogeogr. Palaeocl., 259, 341-356, 2008.

Wagner, B., Lotter, A. F., Nowaczyk, N., Reed, J. M., Schwalb, A., Sulpizio, R., Valsecchi, V., Wessels, M., and Zanchetta, G.: A 40000 -year record of environmental change from ancient Lake Ohrid (Albania and Macedonia), J. Paleolimnol., 41, 407-430, 2009.

Willis, K. J.: The vegetational history of the Balkans, Quaternary Sci. Rev., 13, 769-788, 1994.

Zander, J. M., Caspi, E., Pandey, G. N., and Mitra, C. R.: The presence of tetrahymanol in Oleandra wallichii, Phytochem., 8, 2265-2267, 1969. 